\title{
Algemene aspecten van financieel toezicht in Nederland
}

\author{
Arjan Scheltema en Michiel Scheltema
}

\section{Inleiding}

Uw Vereniging heeft ons gevraagd een preadvies te schrijven over het financieel toezicht in Nederland. Dit sloot goed aan op het preadvies over financieel toezicht dat wij kortgeleden uitbrachten voor de Vereniging voor effectenrecht in Nederland. ${ }^{\mathrm{I}} \mathrm{De}$ actualiteit van het onderwerp leent zich zeker voor verdere discussie.

Tegelijkertijd preadviseren onze Belgische collega's over het toezicht op de energiesector. Hoewel beide sectoren gelijkenis vertonen, zijn er ook aanzienlijke verschillen, zodat de vergelijking tussen het toezicht in beide sectoren niet zonder meer mogelijk is. Teneinde een zo vruchtbaar mogelijke discussie over beide preadviezen te bevorderen, hebben wij in dit preadvies de volgende werkwijze gekozen.

Wij hebben het eerste deel van ons eerdere preadvies tot uitgangspunt gekozen. Dat behandelt enkele algemene vragen omtrent de wijze waarop het toezicht in de financiële sector ingericht moet worden. In dit preadvies bouwen wij daarop in zoverre voort, dat wij in het verlengde daarvan willen nagaan in hoeverre de conclusies voor de financiële sector veralgemeniseerd kunnen worden. Ons ontbreekt voldoende kennis van de energiesector om dit geheel toe te snijden op die sector, maar wij zullen waar mogelijk toch de energiesector bij die veralgemenisering betrekken.

Voor de Nederlandse situatie heeft dat nog een bijzonder voordeel. Een belangrijk onderscheid tussen de energiesector en de financiële sector was tot nu toe dat de energiebedrijven in belangrijke mate in handen van overheden waren. De laatste tijd is die situatie als gevolg van de privatisering ingrijpend veranderd. Grote stroomproducenten zijn of komen in handen van private, vaak buitenlandse, bedrijven. Het gevolg daarvan is dat het publieke belang niet meer bewaakt kan worden door de overheden als aandeelhouders. Daardoor komt het accent voor de behartiging van het publieke belang veel sterker op de regulering en het toezicht te liggen. Dit maakt de vergelijkbaarheid van de problematiek met die in de financiële sector groter. Daar zijn de aandeelhouders altijd al private partijen geweest, en moet het publieke belang - dat blijkens de crisis ook in deze sector heel groot is - door regulering en toezicht worden bewakt. In Nederland moet de energiesector nog aan die situatie wennen. De ervaringen in de financiële sector, voor zover die zich lenen voor een meer algemene toepassing, kunnen daarbij behulpzaam zijn.

I. A.H. Scheltema en M. Scheltema, Financieel toezicht in bestuursrecht en privaatrecht, Noodzakelijke veranderingen na de crisis, Serie Van der Heijden Instituut deel IoI, Kluwer 2009. 
De opbouw van dit preadvies is daardoor als volgt.

Allereerst wordt een uiteenzetting gegeven van het relevante deel van ons eerdere preadvies. Dat is bijna geheel aan dat preadvies ontleend, zij het dat de beschouwingen wat beknopter zijn gehouden, waarbij bovendien aspecten die heel specifiek zijn voor het financiële toezicht niet zijn behandeld. Het accent ligt dus op die beschouwingen die zich kunnen lenen voor toepassing in andere sectoren. Tegelijkertijd zijn die beschouwingen op een enkele plaats aangevuld met bevindingen ontleend aan recente ontwikkelingen.

Daarna wordt de vraag behandeld in hoeverre onze bevindingen ook kunnen opgaan buiten de financiële sector. De energiesector is stellig een terrein waar die vraag duidelijk naar voren komt.

Onze Belgische collega's hebben zich voorgenomen ook aandacht te besteden aan het vraagstuk van de aansprakelijkheid van toezichthouders. Die vraag hebben wij niet eerder behandeld, maar er zijn in Nederland een tweetal recente rapporten over de aansprakelijkheid van de toezichthouder verschenen, die interessant zijn en mede de algemene aspecten van aansprakelijkheid van toezichthouders behandelen. Vandaar dat wij aan het slot in dit preadvies kort op dat onderwerp zullen ingaan.

\section{$2 \quad$ Algemene aspecten bij toezicht op (financiële) markten}

Publiekrechtelijke regulering en toezicht zijn nodig indien het publieke belang sterk is betrokken bij het functioneren van een bepaalde sector, en niet kan worden aangenomen dat die publieke belangen 'vanzelf', dus zonder overheidsoptreden, via de markt behartigd zullen worden.

Dat het publieke belang in sterke mate betrokken is bij het functioneren van de financiële sector is het uitgangspunt geweest bij het opstellen van de financiële toezichtwetgeving. Een en ander behoeft in de huidige tijd geen nadere toelichting. Het is overigens interessant te constateren dat het toezicht in de financiële sector enkele decennia geleden veel beperkter was dan tegenwoordig. De wetgeving is dan ook onstuimig gegroeid. De sector heeft een aantal specifieke kenmerken die een ingrijpende overheidsbemoeienis rechtvaardigen.

\section{I Kenmerken financiële sector}

Groot strategisch belang banken en verzekeraars

Banken en verzekeraars zijn voor de gehele economie van groot strategisch belang. Het omvallen van instellingen, het wegvallen van het vertrouwen in banken en verzekeraars en het disfunctioneren van financiële markten brengt de gehele economie in gevaar. Dat rechtvaardigt een veel ingrijpender overheidsbemoeienis dan bij andere sectoren van de economie.

Ondoorzichtigheid van risico's op financiële markten

Veel van de producten op de financiële markten kennen een risico-element. Hun waarde kan afhankelijk zijn van factoren als de toekomstige ontwikkeling van een 
bepaald bedrijf of van de economie als geheel, van de toekomstige rentestand of van de toekomstige prijzen van huizen of van andere goederen. Zoals de ervaring steeds weer leert, is een goede inschatting van die risico's veelal niet mogelijk. Wel geldt vaak dat degene die over de beste gegevens beschikt, een beter inzicht heeft dan anderen. Daaruit volgt dat insiders in het voordeel zijn boven outsiders. Voor het publieke belang heeft dit twee consequenties.

In de eerste plaats is een rationele bepaling van de prijs van veel producten op de financiële markten lastiger dan in andere markten. Dat bemoeilijkt een goed functioneren van de financiële markten, een effect dat nog wordt versterkt als professionele organisaties enerzijds en consumenten anderzijds transacties aangaan. Daardoor kan er meer aanleiding bestaan voor een goede bescherming van consumenten dan elders nodig is. Dit geldt in het bijzonder voor die producten, die voor de consument een langjarige verbintenis opleveren waarvan zijn financiële situatie in sterke mate afhankelijk is. Dat is meestal het geval bij hypotheken en pensioenvoorzieningen en kan zich ook daarbuiten voordoen.

In de tweede plaats kunnen cumulatieve effecten optreden als risico's zich verwezenlijken die in de markt systematisch zijn onderschat. Een risico, verbonden met de ontwikkeling van de waarde van een huis of een effectenportefeuille, kan een onverwacht nadeel opleveren dat voor de betrokkene ernstig kan zijn. Echter als vele transacties van dezelfde soort zijn afgesloten, kunnen cumulatieve effecten voor de economie als geheel ontstaan. De huidige kredietcrisis is daar een voorbeeld van.

De grote invloed van transacties op de financiële positie van mensen

Hoewel dat lang niet voor alle transacties geldt, zijn er enkele soorten van transacties op de financiële markten die een langdurige en soms levenslange invloed hebben op de financiële positie van mensen. Dit geldt in ieder geval voor de meeste hypotheken en pensioenen. Dit betekent dat het niet goed functioneren van deze sector tot grote maatschappelijke en economische problemen kan leiden. De overheid kan daar ook direct nadeel van ondervinden doordat het beroep op inkomensondersteuning toeneemt.

\subsection{Doelstellingen van de regulering en het toezicht in de financiële sector}

De wetgever heeft in het verleden de publieke belangen die nopen tot regulering en toezicht in algemene termen als volgt omschreven:

'De doelstelling van de financiële toezichtswetten is tweeledig: in de eerste plaats het beschermen van de "afnemers" van de diensten die door de betrokken financiële ondernemingen worden aangeboden of verricht en in de tweede plaats het bevorderen van de goede werking van de financiële markten en het handhaven van het vertrouwen in de financiële sector. Het gaat dus zowel om het belang van de individuele belegger, bankcrediteur en polishouder als om het functioneren van de desbetreffende markten en de financiële sector in het algemeen. De genoemde doelstelling behoeft nauwelijks toelichting. Het belang van de integriteit en het goed functioneren van de financiële sector is van essentieel belang voor de economie en 
ook in internationaal verband onomstreden. Wel kan hier nog worden opgemerkt dat het toezicht op de individuele financiële ondernemingen bijdraagt aan het vertrouwen in zowel de te onderscheiden financiële markten als de financiële sector in zijn geheel. Verder is een belangrijk uitgangspunt bij het toezichtsbeleid en bij het formuleren van de concrete toezichtseisen, dat recht wordt gedaan aan de eigen verantwoordelijkheid en de beleidsvrijheid van deze instellingen. Dit laatste is van belang om ruimte te bieden aan onderlinge concurrentie op het gebied van prijs, kwaliteit van de dienstverlening en productinnovatie.' ${ }^{2}$

Deze algemene doelstelling wordt onderscheiden in een tweetal onderdelen: het prudentiële toezicht en het gedragstoezicht (inclusief marktoezicht). Deze vormen van toezicht zijn ook organisatorisch van elkaar onderscheiden, doordat zij ieder een eigen toezichthouder kennen. De Nederlandse Bank oefent het prudentiële toezicht uit en de Autoriteit Financiële Markten het gedragstoezicht. ${ }^{3}$

Het prudentiële toezicht is gericht op het voorkomen dat banken omvallen. Anders dan bij gewone bedrijven heeft het risico dat een bank of verzekeraar failliet gaat zodanig ernstige gevolgen dat dit zoveel mogelijk moet worden voorkomen. Voor (levens)verzekeraars geldt nog in het bijzonder dat een gebrek aan goede financiering eerst op zeer lange termijn behoeft te blijken, zodat ook om die reden de gewone regels over faillissement niet bruikbaar zijn.

Het prudentiële toezicht is een vorm van toezicht dat zich richt op de wijze waarop financiële ondernemingen hun interne bedrijfsvoering inrichten. Hiermee onderscheidt het zich van het gedragstoezicht, dat betrekking heeft op de wijze waarop de financiële markten functioneren. Daarbij staat niet de instelling, maar de transactie op de markt centraal. Een en ander brengt met zich mee dat de inrichting van beide vormen van toezicht sterk verschillend is.

Het gedragstoezicht richt zich op het goed functioneren van de financiële markten.

Een aantal factoren vormt een belemmering voor een goede marktwerking. ${ }^{4}$ In de eerste plaats is dat het verschil in informatie positie van de verschillende deelnemers aan de markt. Een markt werkt alleen goed als alle partijen over de relevante informatie beschikken. Dat is op de financiële markten geenszins een gegeven: er

2. Kamerstukken II I995-I996, 24843 , nr I, p 3.

3. Zie ook Grundmann-Van der Krol, Koersen door de Wet op het financieel toezicht, Den Haag, 2008, p. 30 e.v.. Zie voor algemene beschouwingen over de redenen voor regulering van financiele markten, P. Cartwright, Bank, Consumers and Regulations, Oxford: Hart 2004, p. I3 e.v. Hij beschrijft overtuigend dat niet alleen marktfalen een reden voor regulering is, maar dat er ook sociale redenen zijn die regulering rechtvaardigen, zelfs als dat economisch niet efficiënt is; zoals sociale normen en sociale rechtvaardigheid. Zie over de noodzaak voor regulering voorts M.P. Boots, D. Schoenmaker, Het doel van de Wft: een economische benadering, in D. Busch e.a., Onderneming en financieel toezicht, Deventer 2007, p. I3 e.v. en de daar aangehaalde literatuur.

4. Zie over marktfalen R.H.J. van Bijnen, W.H. van Boom, Nietigheid bij overtreding van financiële toezichtswetgeving, Position paper uitgebracht door Tilburg Institute for Law and Economics TILEC in opdracht van directie Financiële Markten ministerie van Financiën, 23 juni 2005 (hierna het TILEC-rapport), p. II en W.H. van Boom, Financiële toezichtswetgeving en nietige overeenkomsten, VrA 2006-I, p. I6 en de daar geciteerde literatuur. 
is welhaast steeds een verschil tussen insiders en outsiders. Het bevorderen van de transparantie is dan ook een eerste onderdeel van het publieke belang op het terrein van het gedragstoezicht. 5

Een tweede punt betreft de bescherming van de consument. Naast professionals zijn individuele burgers zonder kennis en ervaring belangrijk: zij kopen een groot aantal van de producten die op de markt omgaan. Maar zij zijn vaak niet goed uitgerust om de professionele wederpartij voldoende tegenspel te bieden. De bescherming van hun positie is dan ook een tweede onderdeel van het publieke belang bij het gedragstoezicht.

Tenslotte is het publieke belang betrokken bij mogelijk cumulatieve effecten van transacties op de markt. Het is goed denkbaar dat een individuele transactie geen enkel gevaar voor het publieke belang inhoudt, maar dat de cumulatie van een groot aantal transacties van dezelfde soort dat wel doen. Dit laat zich met name denken als het resultaat van vele contracten sterk afhankelijk is van het optreden van een hetzelfde risico met een algemeen karakter, zoals de stijging van de rente, het intreden van een recessie of het verloop van de effectenkoersen.

De huidige vormgeving van het gedragstoezicht richt zich op de beide eerstgenoemde belangen: transparantie en bescherming van consumenten. Het laatstgenoemde belang heeftnog niet of nauwelijks de aandachtvan dewetgever getrokken.

\section{De inrichting van het toezicht in de financiële sector}

\section{I Inleiding}

Gezien de grote publieke belangen die bij het goed functioneren van de financiële markten zijn betrokken en de omvang van de crisis die nu door het disfunctioneren van financiële ondernemingen is ontstaan, kan men zich geheel andere benaderingen van het toezicht voorstellen dan op dit moment gelden.

Aan de ene kant is denkbaar dat men financiële ondernemingen veel meer onder de zeggenschap van de overheid brengt, met als meest vergaande variant de (re)nationalisatie van (bepaalde) financiële ondernemingen. Wanneer stemmen opgaan die het 'einde van het kapitalisme' naderbij zien komen, wordt in deze richting gedacht. Aan de andere kant wordt gepleit voor een sterke uitbreiding van regulering en toezicht, nu de huidige arrangementen kennelijk hebben gefaald.

In beide benaderingen wordt de oplossing in de publiekrechtelijke sfeer gezocht. Minder aandacht lijkt te bestaan voor de vraag of publiekrecht en privaatrecht niet beter op elkaar afgestemd moeten worden. In de huidige gedachtegang ligt de verantwoordelijkheid voor het publieke belang geheel in handen van de overheid. Door bestuursrechtelijke regulering en toezicht moet worden bereikt dat er in de financiele sector geen problemen ontstaan. De financiële ondernemingen waarop toezicht wordt gehouden kennen een zodanige privaatrechtelijke structuur dat het nemen

5. Zie bijvoorbeeld artikel I:25 Wft en Grundmann-van der Krol, p. I4 e.v. 
van enige eigen verantwoordelijkheid voor de publieke belangen wordt tegengewerkt. Dat is in strijd met het uitgangspunt van de wetgever, die het belang van die eigen verantwoordelijkheid benadrukt. Het is ook in strijd met de eisen die het toezicht op een zo gecompliceerde sector als de financiële stelt. Als de privaatrechtelijke regels over de inrichting van financiële ondernemingen niet veranderen, kunnen de publieke belangen door het publiekrecht alleen onvoldoende worden beschermd. Dan is nationalisatie van banken en verzekeraars de enige oplossing, een oplossing die wij niet voorstaan.

Hieronder zullen wij onze stelling toelichten.

\subsection{Regulering en toezicht betreft professionele instellingen}

De huidige regulering en het huidige toezicht is gericht op financiële ondernemingen, die zijn te beschouwen als professionele organisaties.

Het prudentiële toezicht is uit de aard der zaak gericht op financiële ondernemingen. In de praktijk is dat ook het geval bij het gedragstoezicht. Bij transacties in de sfeer van het bank- en effectenrecht is een van de partijen doorgaans een financiële onderneming: een bank, een verzekeraar of een uitgever van effecten. Veel transacties mogen ook alleen maar door een dergelijke instelling worden verricht. Dat betekent dat er steeds een professionele organisatie betrokken is bij de transacties waarop het toezicht gericht is.

Bij deze stand van zaken ligt het voor de hand dat wetgeving en toezicht vooral gericht zijn op het gedrag van de professionele partij. Als bereikt kan worden dat deze handelt in overeenstemming met de regels van de wet, zal de wetgever zijn doel hebben bereikt. Het gedrag van de wederpartij - de cliënt van de bank, de koper van effecten of de verzekerde - behoeft weinig specifieke aandacht: zolang de financiële onderneming op de door de wetgever gewenste wijze optreedt, zullen de publieke belangen zeker zijn gesteld. Er zijn dan ook weinig regels te vinden die zich op disciplinering van die wederpartij richten.

Dit gegeven is van belang omdat het disciplineren van een professionele organisatie of van professionals specifieke eisen stelt en mogelijkheden biedt. Dit geldt zowel voor de inrichting van de wetgeving als voor het toezicht.

\subsection{Regulering van professionele organisaties: open normen of gedetailleerde voorschriften?}

Een belangrijke vraag in dit verband is die naar de soort regels die het meest geschikt zijn om een professionele organisatie te disciplineren. Onze stelling is dat open normen in dat geval doorgaans beter geschikt zijn dan gedetailleerde gedragsvoor- 
schriften. Wanneer die stelling juist is, heeft dat gevolgen voor de inrichting van de wetgeving en ook van het toezicht. ${ }^{6}$

Van oudsher bestaat er in het recht een voorkeur voor duidelijke regels, die precies aangeven welke gedrag in een bepaalde situatie verlangd wordt. De burger kan dan eenvoudig vaststellen waar hij aan toe is. Het toezicht op de naleving is meestal ook eenvoudig omdat de overtreding is vast te stellen zonder dat over de interpretatie van de regel behoeft te worden nagedacht.

Wanneer de norm is dat voor de uitgifte van effecten een goedgekeurde prospectus vereist is, zal het eenvoudig vast te stellen zijn of die norm is nageleefd. Maar wanneer wordt voorgeschreven dat de uitgevende instelling tijdig alle relevante informatie moet verstrekken, of dat de bank de belangen van de cliënt zorgvuldig moet bewaken, is dat minder gemakkelijk. In dat geval is het nodig om zowel de vereiste kennis te hebben over de betekenis die deze norm in de praktijk heeft gekregen - hetgeen kennis van jurisprudentie of professionele praktijken vergt - als om uitvoeriger feitenonderzoek te doen naar het gedrag van de bank.

Een en ander brengt met zich mee dat zowel de naleving van de norm als de handhaving ervan in het eerste geval eenvoudiger is dan in het tweede. Degene tot wie de norm gericht is, is goed in staat om te bepalen wat hij moet doen. Hij weet dus precies waar hij aan toe is. In dit geval: de prospectus laten goedkeuren voordat hij de effecten uitgeeft. En de handhaver heeft het eveneens gemakkelijk: de overtreding van de norm is eenvoudig vast te stellen. Dat geldt zowel wanneer men op privaatrechtelijke instrumenten vertrouwt om naleving af te dwingen, als in geval van overheidstoezicht.

Is daarom een gedetailleerde regelgeving vanuit het gezichtspunt van de handhaving het meest aantrekkelijke, er zijn ook argumenten die daar juist tegen pleiten. In het algemeen geldt dat een activiteit die een sterk routinematig karakter heeft, het beste met behulp van strakke voorschriften valt te normeren. Maar als niet alleen routine, maar ook het beoordelen van vele omstandigheden en het verwerken van mogelijk nieuwe inzichten een rol spelen, wordt dat moeilijker. De regelgever kan immers maar met een beperkt aantal omstandigheden rekening houden: anders worden de regels te ingewikkeld. Als de omstandigheden voortdurend veranderen, of als nieuwe kennis in hoog tempo wordt ontwikkeld, zal de wetgever daarbij steeds achter lopen.

Een kenmerk van de huidige, snel internationaliserende kennissamenleving is dat zowel de omstandigheden als de kennis in hoog tempo veranderen. Een deel van de

6. Zie voor 'principle based' regelgeving in het kader van het financiële recht onder meer, Grundmann-van der Krol, p. I76, 225, 433 en 476, en zie in positieve zin over 'principle based' regelgeving M. Hage, Principle-based toezicht, Bank en Effectenbedrijf, november 2007, p. 8-II en het Jaarverslag 2005 van de Autoriteit Financiële Markten en daarover ook J.S.L.M Hillen, Jaarverslag 2005 van de Autoriteit Financiële Markten, Tijdschrift voor Financieel recht, p. IIo e.v. en zie in minder positieve zin V.P.G. de Serière, Luiheid opportunisme of wijsheid?, Principle based regelgeving in het financiële recht, Ondernemingsrecht 2008, p. 99 en M. van Driel, Uit de compliancepraktijk 'Beter regulation: objective or oxymoron' Tijdschrift voor Compliance 2006-3, p. 55-56. 
maatschappelijke activiteiten hebben nog wel een routinematig karakter en worden dan meestal geautomatiseerd. Zo wordt in de financiële sector het betalingsverkeer - dat vroeger bij banken veel werk verschafte - geautomatiseerd afgedaan. Maar daarnaast staan activiteiten die er juist uit bestaan dat een beslissing of een overeenkomst een inschatting vergt van vele omstandigheden die relevant zijn en actuele kennis veronderstelt over vele onderwerpen. De vraag welke informatie over een bedrijf relevant is bij de opstelling van een prospectus, of wat een bank moet doen om de zorgplicht jegens een bepaalde cliënt na te komen, is alleen in abstracte termen door de regelgever te beantwoorden. Het concrete antwoord zal steeds veranderen: in een opgaande conjunctuur zal het anders zijn dan in een neergaande en in crisissituatie zal nog weer anders gehandeld moeten worden. Dat alles valt niet tevoren in gedetailleerde regelgeving vast te leggen.

Men kan het ook anders zeggen. In een samenleving waarin omstandigheden snel kunnen veranderen en waarin kennisontwikkeling van grote betekenis is, wordt een professioneel handelen steeds belangrijker. Met professioneel handelen wordt hier bedoeld een handelen dat geen routinematig karakter heeft, maar dat steeds een inschatting vergt van alle relevante omstandigheden en van toepassing van de nieuwste kennis.

Het handelen van een arts kan als een duidelijk voorbeeld van professioneel handelen worden gezien. Het valt niet in strakke regels vast te leggen; misschien wel voor een deel, maar niet in algemene zin. Nieuwe inzichten en ervaringen moeten steeds worden meegenomen.

De financiële sector is een voorbeeld van een gebied waarin het belang van professionaliteit sterk is toegenomen. Nieuwe instrumenten en producten hebben zich met grote snelheid ontwikkeld en de omstandigheden zijn aan een voortdurende verandering onderhevig. De gevolgen van de globalisering, van de internationale verwevenheid van financiële ondernemingen en van het bedrijfsleven en van nieuwe technische vindingen hebben een voortdurend effect op de waarde en de risico's van de producten. Dit alles stelt hoge eisen aan de kennis en het beoordelingsvermogen van hen die in de sector werkzaam zijn.

In het rapport De toekomst van de nationale rechtsstaat ${ }^{7}$ heeft de WRR in meer algemene zin geconcludeerd dat professioneel handelen in de huidige kennissamenleving steeds belangrijker wordt. Daaruit wordt afgeleid dat de wijze van reguleren en toezicht houden daaraan moet worden aangepast: strakke regulering (en daarmee verbonden strak toezicht) kunnen dan snel contraproductief worden. Zij hinderen de vooruitgang, omdat vernieuwing en creativiteit worden tegengehouden ten gunste van routinematig gedrag. De regels lopen steeds achter wanneer de omstandigheden veranderen of nieuwe inzichten ontstaan.

Voor de financiële sector betekent dit dat de regulering toegesneden moet zijn op de professionele benadering die in de sector belangrijk is geworden. Wanneer door concurrentie de creativiteit en vernieuwing bevorderd moet worden, is strakke regulering een belemmering. De voordelen van goed functionerende markten is immers

7. Wetenschappelijke Raad voor het Regeringsbeleid, De toekomst van de nationale rechtsstaat, Rapporten aan de regering no. 63, Den Haag 2002. 
juist dat door mededinging de inventiviteit wordt gestimuleerd en vernieuwing wordt bevorderd. Naarmate de regulering gedetailleerder is, is concurrentie minder goed mogelijk, zodat de activiteit een meer routinematig karakter dreigt te krijgen. In die situatie wordt onvoldoende geprofiteerd van de voordelen die de markt kan bieden. Bij de totstandkoming van de voorlopers van de Wet financiële toezicht is dat al uitdrukkelijke onderkend. In het eerder aangehaalde citaat uit de memorie van toelichting staat daarover:

'Verder is een uitgangspunt dat bij het toezichtsbeleid en bij het formuleren van concrete toezichtseisen, dat recht wordt gedaan aan de eigen verantwoordelijkheid van deze instellingen. Dit laatste in van belang om ruimte te bieden aan onderlinge concurrentie op het gebied van prijs, kwaliteit van dienstverlening en productinnovatie.' 8

Dit betekent dat de regels en het toezicht ruimte moeten laten voor de professionele verantwoordelijkheid die de financiële onderneming zelf dient in te vullen. Dat veronderstelt niet alleen dat de regels een daarvoor voldoende open karakter hebben, maar heeft ook gevolgen voor de inrichting van het toezicht. Over de manier waarop het toezicht dan moet worden ingericht, handelt de volgende paragraaf.

Wel is het goed er reeds hier op te wijzen dat de aangehaalde passage uitgaat van de eigen verantwoordelijkheid van de financiële onderneming. De onderneming moet die verantwoordelijkheid dan ook nemen. Gebeurt dit niet, dan schiet een daarop afgestemd toezicht tekort. Dat kan tot gevolg hebben dat steeds strakkere regels worden geformuleerd en het toezicht steeds strenger wordt. Dan rijst wel de vraag of de aansturing dan niet beter direct door de overheid zelf kan geschieden: het hierboven genoemde perspectief van nationalisatie kan dan aantrekkelijk worden. Het vertrouwen op de eigen verantwoordelijkheid van de onderneming stelt dan ook eisen aan de inrichting van die onderneming.

\subsection{Toezicht op professionele organisaties: accent op tweedelijns toezicht}

Als het toezicht gericht is op de vraag of bepaalde nauwkeurig geformuleerde regels zijn nageleefd, gaat het om een relatief eenvoudige vorm van toezicht. Het verzamelen van de feiten is - hoewel soms moeilijk - daarbij de grootste opgave. Is het toezicht sterker gebaseerd op meer open normen, toegesneden op de professionaliteit van de onder toezicht gestelde organisaties, dan stelt dat hogere eisen aan de toezichthouder. Het toepassen van meer open normen in een concrete situatie is lastiger te beoordelen en vergt het bezit van veel professionele kennis. Dat wordt bijzonder arbeidsintensief als men alle gevallen wil controleren. Meestal is het dan ook noodzakelijk een toezichtbeleid te ontwikkelen dat via steekproeven, klachten en risicoanalyse de controle zo effectief mogelijk maakt.

8. Kamerstukken II I995/96, $24843, \mathrm{nr}$ I, p 3. 
Voordelen van tweedelijns toezicht

Een benadering van controle die goed aansluit bij professionele organisaties, stelt de eigen verantwoordelijkheid van de organisatie om zich aan de regels te houden voorop. Uitgangspunt is dan dat de instelling een beleid moet voeren om te zorgen dat men zich houdt aan de regels. Zonder een systematisch daarop gericht beleid is het voor een instelling immers niet doenlijk om te verzekeren dat alle medewerkers van de organisatie zich dienovereenkomstig gedragen.

Het eerste wat een toezichthouder dus zou moeten doen is nagaan welke voorzieningen de instelling heeft getroffen om de naleving van de regels te verzekeren. Als voorzieningen ontbreken, is aanstonds al duidelijk dat de instelling tekort schiet. Vervolgens komt de vraag aan de orde of de getroffen voorzieningen toereikend zijn. Welke maatregelen heeft men getroffen om te verzekeren dat alle onderdelen van de organisatie de regels kennen en zich daarnaar gedragen en welke vormen van controle heeft men voorzien? De aard van de voorzieningen zal uiteraard samenhangen van de soort regels waar het om gaat, het karakter van de organisatie, de omstandigheden waaronder die moet functioneren en de voorhanden professionele kennis om de doelstellingen waarop het toezicht zich richt, te bereiken.

Deze vorm van tweede lijns toezicht - of meta-toezicht - heeft een aantal belangrijke voordelen. Zij maakt gebruik van het feit dat het toch in eerste instantie de instelling zelf is die verantwoordelijk is voor het opvolgen van de regels. De vraag hoe dat het beste binnen de organisatie bereikt kan worden kan doorgaans beter beantwoord worden door de professionals en bestuurders van de instelling zelf, dan door buitenstaanders. In dat opzicht heeft de toezichthouder altijd een informatieachterstand. Zou het toezicht alleen gericht zijn op de regelnaleving in concrete gevallen, dan behoeft de instelling niet na te denken over de vraag hoe zij zelf de normoverschrijding kan tegengaan. De vraag voor de instelling is dan veeleer: hoe kan ik bereiken dat de toezichthouder tevreden is? Dat resultaat kan behaald worden door de regels zorgvuldig na te leven, maar ook door de activiteiten zodanig in te richten dat mogelijke normoverschrijdingen door de toezichthouder moeilijk te ontdekken zijn. Het is lang niet altijd zeker dat de eerste handelwijze voor de instelling profijtelijker is dan de tweede.

Het voordeel van tweedelijns toezicht is dat de instelling ook zelf de eerste verantwoordelijkheid draagt voor het organiseren van het eerstelijns toezicht. Uiteraard geldt ook hier dat zij kan trachten de toezichthouder zand in de ogen te strooien door een minder effectief of minder waterdicht stelsel op te zetten, maar dat zal meestal toch moeilijker zijn. De mogelijkheid om een dergelijk stelsel goed te borgen, eventueel met behulp van externe deskundigheid, is vaak aanwezig. Dat neemt niet weg dat de toezichthouder de mogelijkheid moet hebben om steekproefsgewijs in concrete gevallen na te gaan of het beoogde resultaat - het naleven van de regels wordt bereikt.

Er is een tweede argument ten gunste van het tweedelijns toezicht te geven. Dat betreft de professionaliteit die nodig is voor het beoordelen van complexe financiele producten. Er komen voortdurend nieuwe producten en de betekenis ervan kan ook sterk wisselen met de omstandigheden. De toezichthouder heeft bijna altijd een informatieachterstand ten opzichte van degenen die de producten ontwikkelen en 
in het verkeer brengen. Daarom zou in eerste instantie van de instelling zelf verlangd moeten worden dat zij op transparante wijze aangeeft hoe dit product zich verhoudt tot de doelstellingen van het toezicht en wat dus de consequenties zijn van de vernieuwing. Bij het gedragstoezicht gaat het dan om de vraag naar de kosten en risico's van het product en de maatregelen die nodig zijn om te voorkomen dat het terecht komt bij onvoldoende geïnformeerde professionele partijen of bij consumenten voor wie het niet geschikt is. Bij het prudentiële toezicht gaat het om de vraag welke risico's precies aan het product kleven en hoe die gewaardeerd moeten worden in verschillende omstandigheden.

Het kortgeleden verschenen rapport over een onderzoek in opdracht van het WODC (Wetenschappelijk onderzoek en documentatiecentrum van het Ministerie van Justitie) over 'systeemtoezicht' 9 denkt sterk in de hier geschetste richting. Het rapport beschrijft een ontwikkeling van 'klassiek' toezicht - voldoet een product of prestatie van de ondertoezicht gestelde aan de norm? - naar systeemtoezicht. Dat systeemtoezicht wordt omschreven als 'al dat toezicht waarbij de opzet, reikwijdte en werking van (kwaliteits)systemen en bedrijfsprocessen bij organisaties wordt vastgesteld. Dit door audit-achtige onderzoeken met realitychecks uit te voeren'. Het systeemtoezicht maakt daarbij gebruik van zelfregulerende systemen binnen de organisaties of branches. ${ }^{\text {IO }}$ De kunst van het systeemtoezicht is dan ook om de onder toezicht gestelde 'eigenaar' van de norm te laten worden. ${ }^{\mathrm{II}}$ Wij zouden liever niet over 'norm' spreken, maar iets ruimer de nadruk leggen op de eigen verantwoordelijkheid die de instelling aan de dag moet leggen voor het publieke belang. Maar het is duidelijk waar het om gaat: de instelling zelf moet een beleid ontwikkelen, en dus systemen inrichten, gericht op het bewaken van het betrokken publieke belang, en de toezichthouder moet zich vooral richten op de vraag of dat beleid en die systemen adequaat zijn.

Voor een zestal sectoren is op deze ontwikkeling ingegaan, waaronder ook de financiële sector. Uit het rapport blijkt dat de AFM is begonnen met een project Toezicht op Maat, ${ }^{12}$ dat als een vorm van tweedelijns toezicht of systeemtoezicht op financiële instellingen is te beschouwen. Het is nog in ontwikkeling en lijkt zich beter te lenen voor toezicht op grote instellingen dan op kleine organisaties of eenmanskantoren. Dat laat zich in de huidige opzet goed begrijpen. Bedacht kan wel worden dat in andere sectoren ook vormen van toezicht op individuele professionals bestaan, waarbij organisaties van professionals ook een rol spelen.

Uit het rapport komt naar voren dat de oorspronkelijke veronderstelling dat systeemtoezicht minder lasten met zich mee zou brengen, niet zonder meer juist is.

9. Jan-Kees Heldeman en Marlies Honingh, Systeemtoezicht, een onderzoek naar de condities en werking van systeemtoezicht in zes sectoren, Boom juridische uitgevers, Den Haag 2009.

Io. Jan-Kees Heldeman en Marlies Honingh, Systeemtoezicht, een onderzoek naar de condities en werking van systeemtoezicht in zes sectoren, Boom juridische uitgevers, Den Haag 2009, p. 89.

II. Jan-Kees Heldeman en Marlies Honingh, Systeemtoezicht, een onderzoek naar de condities en werking van systeemtoezicht in zes sectoren, Boom juridische uitgevers, Den Haag 2009, p. 9I, 94.

I2. Jan-Kees Heldeman en Marlies Honingh, Systeemtoezicht, een onderzoek naar de condities en werking van systeemtoezicht in zes sectoren, Boom juridische uitgevers, Den Haag 2009, p. 70. 
Maar het kan wel leiden tot een beter inzicht in de systemen die gericht zijn op het bevorderen en handhaven van de kwaliteit, zowel bij de toezichthouder als bij de onder toezicht gestelde. Daarvoor is nodig dat de omstandigheden zodanig zijn dat lering kan worden getrokken uit de ervaringen in het verleden en dat er voldoende sprake is van kennisdeling tussen instelling en toezichthouder.

Wij zullen hier verder blijven spreken over tweedelijns toezicht, maar beschouwen het systeemtoezicht zoals omschreven in de WODC publicatie als een nadere vormgeving daarvan.

\section{Beperkingen van de toezichthouder}

Hoewel er grote voordelen verbonden zijn aan een toezicht dat aansluit bij de professionaliteit in de financiële sector en dat althans voor een deel wordt ingekleed in de vorm van tweedelijns toezicht, zijn er ook argumenten die daartegen pleiten.

In de eerste plaats is het lastig voor de toezichthouder om voldoende professionele kennis te verwerven. Die kennis bestaat er in dat men aan de hand van alle relevante omstandigheden en op basis van de actuele stand van de beschikbare kennis kan beoordelen op welke wijze een bepaald belang het beste kan worden gediend. Dat vergt deskundigheid - in de vorm van voldoende kennis van de materie - en professionaliteit - ervaring in het kunnen toepassen van die kennis in uiteenlopende praktijksituaties.

Die ervaring wordt met name opgedaan bij de instellingen waarop de toezichthouder moet letten. Daar doen zich steeds weer nieuwe ontwikkelingen voor en daar worden nieuwe best practices uitgeprobeerd. De beste professionals zullen dus degenen zijn, die in de praktijk bij financiële ondernemingen werkzaam zijn en reeds over voldoende ervaring beschikken. Is men niet meer in de praktijk werkzaam, dan verliest men geleidelijk de kwalificaties waarover een professional moet beschikken, zoals ook een arts die de praktijk heeft verlaten, langzamerhand een minder kundig arts wordt.

Voor de toezichthouder volgt hieruit, dat het verkrijgen en handhaven van voldoende professionele deskundigheid lastig is. Natuurlijk is de noodzakelijke kennis te verwerven en kan men professionals aantrekken die elders ervaring hebben opgedaan. Maar het bijhouden van de nieuwste ontwikkelingen in de praktijk is moeilijk omdat de toezichthouder daar zelf niet aan deelneemt. Men beoordeelt alleen achteraf wat een instelling onder toezicht heeft gedaan. Juist wanneer de voordelen van marktwerking het grootste zijn - dus wanneer door concurrentie innovatieve mogelijkheden worden ontwikkeld - is de achterstand van de toezichthouder ook het grootste. Een latent gevaar voor de toezichthouder is dus dat hij achter de ontwikkelingen aan loopt en de nieuwste gevaren voor het publieke belang bestrijdt met de oplossingen van gisteren. In de tweede plaats zal er bij de toezichthouder een neiging bestaan om de open norm te gaan invullen met nauwkeurige gedragsvoorschriften. Daarvoor bestaan bij de toezichthouder twee sterke argumenten.

Allereerst de omvang van de toezichthouder. Tenzij deze erg klein is, zullen er verschillende personen of afdelingen met toezicht zijn belast. Het is van het grootste belang dat daarbij steeds dezelfde lijn wordt gevolgd: gelijke gevallen moeten door een bestuursorgaan gelijk worden behandeld. Dat wordt bevorderd door in 
(beleids-)regels neer te leggen hoe geoordeeld zal worden. Men kan dan de meest ervaren medewerkers die regels laten opstellen en vervolgens ook minder professioneel geschoolden daarmee laten werken.

Maar ook de onder toezicht staande instellingen zullen daarop aandringen. $\mathrm{Zij}$ willen graag weten in welke gevallen hun gedragingen geaccepteerd zullen worden en in welke gevallen niet. Daarom zullen zij op bekendmaking van door de toezichthouder gevolgde beleidsregels aandringen.

Hier dreigt het gevaar dat de voordelen, die met de meer open normstelling werden beoogd, weer verloren gaan doordat de toezichthouder de open normen gaat vertalen in nauwkeurige voorschriften. De voordelen verdwijnen niet geheel omdat beleidsregels eenvoudiger aangepast kunnen worden aan nieuwe ontwikkelingen dan regels in de wet en ook overigens wat flexibeler zijn, maar toch voor een groot deel. Een bezwaar is daarbij dat een zekere bureaucratie de kop kan opsteken doordat formele vereisten en checklists ontstaan die meer een papieren werkelijkheid beoordelen dan de werkelijke situatie. Voor instellingen die daar 'handig' mee omgaan bergt dit grote mogelijkheden in zich om de eigenlijke, open, norm te ontwijken.

De conclusie moet zijn dat het toezicht op professionele organisaties aan die organisaties de ruimte moet bieden om de eigen inzichten te gebruiken en dus niet het gedrag moet 'dichtregelen'. Dat stelt hoge eisen aan het toezicht, maar ook aan de manier waarop de organisaties waarop het toezicht wordt gehouden, met die eigen verantwoordelijkheid omgaan.

\subsection{Indruk van het huidige toezicht}

De indruk bestaat dat bij de huidige regulering en het huidige toezicht heel sterk wordt uitgegaan van de mogelijkheden voor een publiekrechtelijke toezichthouder om met behulp van toezicht, zowel eerstelijns als tweedelijns, de doelstellingen van de wetgever te bereiken. Tegelijkertijd moet worden geconstateerd dat de hiervoor aangegeven noodzaak om bij toezicht op professionele organisaties aan te sluiten bij de eigen verantwoordelijkheid van die organisaties onvoldoende functioneert. Zij zijn - zo hebben de ervaringen uit de afgelopen twee jaar geleerd - in veel gevallen onvoldoende de 'eigenaar' van het publieke belang waarvoor de toezichthouder staat. $^{\mathrm{I} 3}$

De vraag naar de oorzaak daarvan is niet eenvoudig te beantwoorden. Toch is wel te zeggen dat in ieder geval een deel van de oorzaak is te vinden in het feit dat de financiële ondernemingen hun verantwoordelijkheid onvoldoende hebben genomen. De professionaliteit van die organisaties lijkt vooral te zijn ingezet om de voor hen meest profijtelijke producten te ontwikkelen. Voor wat betreft de mogelijke schade voor de publieke belangen waarvoor het toezicht staat, is de creativiteit

13. In Jan-Kees Heldeman en Marlies Honingh, Systeemtoezicht, een onderzoek naar de condities en werking van systeemtoezicht in zes sectoren, Boom juridische uitgevers, Den Haag 2009, p. 7I wordt een voorbeeld gegeven waarin de financiële instelling kennelijk wel een zekere bereidheid tot mentaliteitsverandering toont. 
vaak te veel gericht geweest op het tevreden stellen van de toezichthouders door met behulp van soms ingenieuze constructies precies aan de regels te voldoen en te weinig op de vraag hoe de schade voor de publieke belangen bij de nieuwe producten zo goed mogelijk kan worden voorkomen. Waarschijnlijk in wisselwerking daarmee hebben regelgever en toezichthouder een zeer omvangrijk stelsel van regels en voorschriften ontwikkeld, dat daar tegenwicht tegen moet bieden, maar dat maar voor een deel heeft kunnen doen. Wel hebben zij geleid tot een op punten bureaucratisch stelsel van regulering en toezicht. Dat levert niet alleen aanzienlijke kosten, maar staat ook haaks op de uitgangspunten die hiervoor zijn uiteen gezet en die ook in de doelstellingen van het financiële toezicht worden weerspiegeld.

\section{Mogelijkheden voor verbetering?}

Het is onze overtuiging dat het toezicht op de financiële sector zo gecompliceerd is, zoveel professionaliteit eist en zozeer moet inspelen op nieuwe ontwikkelingen, dat een stelsel waarin het publieke belang uitsluitend wordt behartigd door de publiekrechtelijke toezichthouder onvoldoende werkt om het publieke belang te beschermen. Als de private partijen hun inventiviteit geheel kunnen richten op het bevorderen van hun eigen belang zolang zij niet door de toezichthouder op de vingers worden getikt en dus geen enkele verantwoordelijkheid nemen om het publieke belang niet te schaden, zullen zij welhaast steeds nieuwe wegen vinden om hun eigen doelstellingen te laten prevaleren boven die waarvoor de toezichthouder staat. Aan de zeer sterke prikkels voor private partijen in die richting, die de laatste jaren nog aan intensiteit hebben gewonnen, kan door een stelsel van publiekrechtelijke regulering en toezicht onvoldoende tegenwicht worden geboden.

Een reactie op de huidige crisis zou kunnen bestaan uit een zodanige strakke regulering, dat voor creativiteit en vernieuwing geen plaats meer is. Dat lijkt niet erg gewenst: dan zouden financiële ondernemingen in feite onderdeel van de overheid worden.

Wil men de voordelen van de markt behouden, dan zullen de prikkels die het gedrag van financiële ondernemingen sturen, niet zodanig haaks moeten staan op het publieke belang als nu het geval is. Er zal ook bij de instellingen ruimte moeten zijn om mede verantwoordelijkheid te nemen voor het publieke belang. Alleen dan krijgt een stelsel van regulering en toezicht, waarbij aangesloten wordt bij de eigen professionele verantwoordelijkheid in de sector, een kans. Met andere woorden: het zodanig inrichten van het toezicht dat ruimte wordt gegeven aan de eigen verantwoordelijkheid van de ondernemingen, veronderstelt dat die verantwoordelijkheid ook in de manier waarop de organisatie is ingericht en het gedrag binnen de organisatie door prikkels wordt gestuurd, daarmee in overeenstemming is. Anders wordt die organisatie niet mede 'eigenaar' van het publieke belang, hetgeen in de termen van het eerder genoemde WODC rapport nodig is.

Dat alles wordt in belangrijke mate bepaald door de wijze waarop het privaatrecht functioneert. Het is het privaatrecht dat de structuur van de onderneming bepaalt en daarmee ook van de vraag welke belangen in het handelen de doorslag moeten geven, inclusief de daarmee te behalen voordelen. Voor financiële ondernemingen geldt dat ook. Daarnaast bestaan er ook in andere delen van het privaatrecht regels die leiden tot incentives die haaks staan op het publieke belang. 
Een bezinning op het toezicht zal daarom mede betrekking moeten hebben op de wijze waarop het privaatrecht vorm geeft aan de structuur van de financiële sector. Daarvoor is naast het verbintenissenrecht ook het ondernemingsrecht (rechtspersonenrecht) van groot belang.

\section{Verankering van het publieke belang in het privaatrecht: het rechtspersonenrecht}

\section{I Inleiding}

Regulering is het minst noodzakelijk als degene wiens gedrag men wil beïnvloeden, geneigd zou zijn uit eigen beweging het publieke belang te dienen. In dat geval zou er geen tegenstelling bestaan tussen het publieke belang en het eigen belang van de instelling. Dat is in wezen ook de reden waarom het goed functioneren van markten zo belangrijk wordt gevonden. Als een markt immers goed werkt, betekent het feit dat iedere deelnemer daaraan zijn eigen belang zo goed mogelijk nastreeft, tegelijkertijd dat het algemeen welzijn wordt bevorderd. De economische prikkels die van de markt uitgaan, leiden in die gedachtegang tot een optimaal resultaat voor de samenleving.

Zoals hierboven geconstateerd bestaat er wel degelijk een tegenstelling tussen het belang dat financiële ondernemingen en andere onder toezicht gestelden nastreven en het publieke belang. Daarom zijn regulering en toezicht ook nodig. Maar de wijze waarop de economische en andere prikkels in de privaatrechtelijke omgeving werken, kan zo tegengesteld worden aan de publieke belangen dat het toezicht daardoor ernstig wordt gefrustreerd.

Als bijvoorbeeld het gedrag van financiële ondernemingen sterk gestuurd wordt door het behalen van winst op korte termijn, of door voordelen die strategische personen binnen die organisatie door een bepaalde handelwijze kunnen behalen, kan hun gedrag strijdig worden met hetgeen men van een goede marktwerking zou verwachten. De instellingen zouden daarmee niet alleen hun eigen doelstellingen op lange termijn kunnen schaden, maar ook de door de overheid behartigde publieke belangen.

De overheid kan dit effect bestrijden door regulering en toezicht. Maar het zal, gelet op hetgeen in het voorgaande is opgemerkt, duidelijk zijn dat regulering en toezicht grotere lasten met zich meebrengen en minder effectief zijn naarmate de tegenstelling tussen de eigen doelstellingen en de daarop afgestemde financiële prikkels van de onder toezicht gestelde organisaties en het publieke belang groter is.

Zeker als het om professionele partijen gaat, ligt hier een groot risico. De inventiviteit die eigen is aan professioneel handelen en die door de werking van de markt wordt gestimuleerd, kan worden aangewend om ondanks het toezicht zo veel mogelijk voordeel te behalen. Naarmate de prikkels die het gedrag sturen, sterker gaan in een richting, tegengesteld aan het publieke belang, zullen financiële 
ondernemingen eerder de grenzen van de regulering en het toezicht opzoeken en daarmee het publieke belang schaden. Het is voor de wetgever en de toezichthouder uiterst moeilijk om hier voldoende tegenwicht te bieden: zij zullen bijna steeds achter de ontwikkelingen aanlopen.

Dat geldt des te sterker als men instemt met het hierboven ingenomen standpunt dat de regulering en het toezicht in de financiële sector moeten inspelen op de professionaliteit van de financiële ondernemingen. Strakke regulering miskent de voortdurend wisselende omstandigheden waaronder gewerkt moet worden en remt door de daarmee verbonden bureaucratie de creativiteit en vernieuwing. Meer open normen en een vorm van toezicht die uitgaat van een eerstelijns eigen verantwoordelijkheid van de financiële onderneming zijn daarom te verkiezen. Een dergelijke benadering is alleen mogelijk indien de professionele oriëntatie in voldoende mate zelf mede gericht is op het behartigen van het publieke belang. De huidige crisis heeft aangetoond dat hier inderdaad een probleem ligt. Innovatie in financiële producten heeft zich zeker voorgedaan als gevolg van de mededinging op de markt, maar de professionele oriëntatie van waaruit die innovatie voortkwam, werd gestuurd door prikkels die eenzijdig gericht waren op het behalen van voordeel op de korte termijn.

Meer regulering en toezicht is daarom niet het beste antwoord wanneer men constateert dat het toezicht tekort schiet. De eerste prioriteit zou moeten zijn te bevorderen dat de professionele oriëntatie en de eigen verantwoordelijkheid bij financiële ondernemingen mede gericht worden op het behartigen van het publieke belang. Wanneer de gedragsprikkels daarop kunnen worden afgestemd, is dat de beste manier om hen te disciplineren. ${ }^{\mathrm{I}}$

Dat roept de vraag op of van privaatrechtelijke organisaties verlangd kan worden dat zij hun werk mede door publieke belangen laten leiden. Komt dat niet in strijd met onze opvattingen over de scheiding tussen publiekrecht en privaatrecht? Hieronder wordt op die vraag ingegaan. In het verlengde daarvan komt de structuur van de financiële onderneming aan de orde.

\subsection{Privaat- en publiekrecht: is alleen de overheid verantwoordelijk voor het publieke belang?}

Het ligt in de traditie van de afgrenzing tussen publiekrecht en privaatrecht dat langs de weg van het publiekrecht gezorgd moet worden voor de publieke belangen. Door duidelijke regels moeten de geboden en verboden worden geformuleerd die daarvoor nodig zijn. Burgers en private organisaties moeten zich aan die regels houden, maar behoeven zich bij hun handelen in de sfeer van het privaatrecht niet

I4. Het belang van goede prikkel wordt ook door andere onderkend, zie bijvoorbeeld P. Cartwright, p. 44, en (zijn verwijzing naar) de Basel Comittee, Core Principles for Effective Banking Supervision, September 1997, en zie bijvoorbeeld ook M.P. Boots, D. Schoenmaker, p. I3, die aangeven dat degene die aan regels moeten voldoen zich veelal naar 'de letter - en niet de geest - van de regels' zullen handelen. 
te bekommeren om de publieke belangen voor zover daarover geen rechtsregels bestaan. Deze duidelijk onderscheiden verantwoordelijkheidsverdeling tussen publiekrechtelijke en privaatrechtelijke organisaties is in het laatste decennium op verschillende manieren onder druk komen te staan.

In de sfeer van de privaatrechtelijke ondernemingen is een beweging opgekomen die het doel van de onderneming minder eenzijdig op het behalen van financieel voordeel legt. Zij wil in het handelen van een onderneming ook een plaats inruimen voor maatschappelijke belangen. In dat verband wordt gesproken van maatschappelijk verantwoord ondernemen. Daarin komt de gedachte tot uitdrukking dat een onderneming niet alleen gericht moet zijn op winstmaximalisatie, maar ook verantwoordelijkheid draagt voor het publieke of algemene belang.

De WRR heeft in zijn eerder genoemde rapport De toekomst van de nationale rechtsstaat $^{15}$ aan deze benadering een analyse ten grondslag gelegd die hier relevant is. De Raad kwalificeert de huidige samenleving als een kennisintensieve samenleving. Dat heeft tot gevolg dat kennis steeds belangrijker wordt bij het maatschappelijk handelen, wat leidt tot grotere behoefte aan professionaliteit. Tegelijkertijd blijkt kennis op vele plaatsen in de samenleving aanwezig te zijn en verder te worden ontwikkeld. Dat heeft tot gevolg dat niet meer op een centraal punt alle kennis is te overzien. Voor regulering door de overheid heeft dat gevolgen: ook een wetgever of een toezichthouder beschikt maar over een beperkte kennis. Degenen voor wie de regels of het toezicht bestemd is, zijn soms beter op de hoogte, zeker als het gaat om de regulering van professioneel handelen. De vraag wanneer het publieke belang schade oploopt en hoe die het beste kan worden voorkomen, kan door de handelende professional vaak beter worden beantwoord dan door de overheid.

De Raad concludeert dan ook dat het niet meer de overheid alleen is die de verantwoordelijkheid voor de publieke belangen kan dragen. Ook de burgers en private organisaties moeten een zekere eigen verantwoordelijkheid daarvoor nemen. De gedachte - wel verbonden met een klassieke opvatting van de rechtsstaat - dat de burger alles mag doen wat de overheid niet verboden heeft, - is in de huidige tijd dan ook (nog) minder houdbaar dan vroeger. Die eigen verantwoordelijkheid hangt samen met het gegeven dat het voor de overheid eenvoudig onmogelijk is geworden al het handelen dat het publieke belang zou kunnen schaden, te sturen of te beheersen.

De professionele waardeoriëntatie

Gezien het belang van het professioneel handelen is de waardeoriëntatie die dat handelen in de private onderneming stuurt een factor van betekenis. Het gaat hier immers niet om gestandaardiseerd of routinematige arbeid, maar om het inzetten van kennis en ervaring om in een bepaald geval het juiste resultaat te bereiken. Wat dat 'juiste resultaat' inhoudt, wordt mede bepaald door waardeoriëntatie van degene die handelt.

I5. Zie hiervoor noot I2. 
Professionals hebben in het algemeen gezamenlijke opvattingen over de maatstaven waarmee zij zichzelf en hun collega's beoordelen. Die maatstaven kunnen onder invloed staan van de aard van de prikkels die aan hun gedrag zijn gerelateerd.

Deze waardeoriëntaties zijn voor een deel een maatschappelijk gegeven. Men kan die niet bij wet veranderen. Tegelijkertijd bestaat er toch vaak een sterke wisselwerking met juridische regels en arrangementen. Het recht weerspiegelt maatschappelijke opvattingen en kan die tegelijkertijd verankeren en versterken. Dat is bij de wijze waarop financiële ondernemingen functioneren sterk het geval: de juridische vormgeving van ondernemingen en de economische prikkels die daardoor zijn ontstaan, hebben een duidelijk stempel gedrukt op de inrichting van hun activiteiten. ${ }^{16}$

Het is duidelijk dat de val van de muur een periode heeft ingeluid waarin het vertrouwen in de vrije markteconomie een grote vlucht heeft genomen. Dat heeft een oriëntatie met zich meegebracht waarin de waarden van de vrije markt zijn benadrukt. Het behalen van economisch voordeel op de korte termijn is dan de dominante doelstelling waarnaar het handelen van financiële ondernemingen wordt beoordeeld. Dat heeft op verschillende manieren grote invloed gehad op de professionele opvattingen over het werk van deze instellingen. Zij zijn verankerd in de juridische structuur van de onderneming, terwijl omgekeerd die structuur leidt tot een verdere versterking van deze opvattingen.

Van belang is daarom wat in dit opzicht de betekenis is van de juridische structuur van financiële ondernemingen. Dat onderwerp komt nu aan de orde.

\section{$5 \quad$ Het publieke belang en de privaatrechtelijke structuur van de financiële onderneming}

Wanneer men de ontwikkeling volgt in de richting van een zekere maatsschappelijke verantwoordelijkheid van ondernemingen, dan zijn banken en verzekeraars wel de eerste voor wie dat zou moeten gelden. Het feit dat overheden zich gedwongen hebben gevoeld vele banken (en verzekeraars) over te nemen of met ingrijpende maatregelen te steunen, geeft aan hoezeer het publieke belang bij het goed functioneren van deze instellingen betrokken is. Bij marktwerking behoort juist dat slecht presterende instellingen failliet gaan en verdwijnen. Zonder dat is in ieder geval niet van een gewone marktwerking te spreken.

$\mathrm{Nu}$ het publieke belang zo duidelijk betrokken is bij het functioneren van de belangrijkste financiële ondernemingen, zou alleen al om die reden de gedachte kunnen opkomen dat het rechtspersonenrecht, dat die structuur bepaalt, aandacht aan de borging van het publieke belang zou besteden. De laatste tijd gebeurt dat ook wel, bijvoorbeeld wanneer wordt voorgesteld de banken te nationaliseren en tot publiekrechtelijke instellingen te maken.

Als men die weg niet op wil gaan, moet toch aan de orde komen of niet langs andere weg kan worden bereikt dat de prikkels die van de inrichting van de onderneming

I6. Het solvabiliteitstoezicht bepaalt zelfs in belangrijke mate op welke manier een bank haar financiële huishouding inricht. 
uitgaan, meer in lijn kunnen worden gebracht met het publieke belang. Omdat regulering en toezicht sterk aan effectiviteit inboeten als de financiële onderneming niet zelf een eigen verantwoordelijkheid neemt voor publieke belangen, is dit een urgent vraagstuk geworden.

Hoe kan bereikt worden dat een financiële onderneming het behartigen van het publieke belang mede ziet als eigen doelstelling? Dat stelt eisen aan de inrichting en de zeggenschapsverhoudingen van de financiële onderneming. Nu het om een privaatrechtelijke organisatie gaat, dient het privaatrechtelijke organisatierecht daarmee rekening te houden.

\section{I De zeggenschapsverhoudingen in de privaatrechtelijke onderneming}

Bij een vanuit winstmaximalisatie gedreven financiële onderneming passen zeggenschapsverhoudingen in ondernemingen en beloningen voor bestuurders die sterk economisch en wellicht ook sterk op de korte termijn, zijn georiënteerd. De meeste grote financiële ondernemingen hebben de rechtsvorm van een naamloze vennootschap. Door de herzieningen in het vennootschapsrecht van de afgelopen jaren, voor een deel ingegeven door de behoefte de mededinging, ook in internationaal verband, te versterken, hebben geleid tot zeggenschapsverhoudingen met een sterke nadruk op de positie van de kapitaalverschaffende aandeelhouders. De eenvoudige verhandelbaarheid van aandelen betekent bovendien dat een langdurige relatie tussen de kapitaalverschaffers en de vennootschap niet verzekerd is. Dit heeft geleid tot een accentuering van het behalen van winst op de korte termijn als dominante doelstelling van de vennootschap. In het verlengde daarvan zijn de beloningen van bestuurders vaak op diezelfde doelstelling gericht.

Gezien het feit dat het publieke belang zo sterk bij een financiële onderneming is betrokken, is het opmerkelijk, en in wezen niet meer aanvaardbaar, dat doelstelling en inrichting van banken en verzekeraars daar in het geheel geen aandacht aan besteden. Dat ligt wat anders bij een enkele instelling die niet de structuur van een vennootschap heeft - de Rabobank is daarvan het bekendste voorbeeld - maar de meeste zijn georganiseerd als een gewone kapitaalvennootschap en daar heeft de hier geschetste ontwikkeling zich duidelijk voorgedaan.

Een tegenwicht zou geboden kunnen worden door het streven naar maatschappelijk verantwoord ondernemen, dat hiervoor werd genoemd. Dat streven wordt door de regering ook omarmd: de staatssecretaris van Economische Zaken heeft de Commissie Burgmans verzocht hierover advies uit te brengen. In het rapport van de Commissie ${ }^{17}$ wordt bepleit dat iedere onderneming een beleid voert, gericht op die maatschappelijke verantwoordelijkheid. Maar de commissie doet geen enkel voorstel om maatschappelijk verantwoord ondernemen in het recht te verankeren. Het lijkt er op dat het een goedbegrepen eigenbelang van ondernemingen is zich (ook) op dit terrein voldoende te onderscheiden.

I7. Aangeboden op 6 november 2008 en te raadplegen op de website van het ministerie van Economische Zaken: www.ez.nl. 
Voor de financiële sector heeft de kredietcrisis wel voor een stroomversnelling in het denken over de structuur van de onderneming geleid. Zo heeft de Nederlandse vereniging van banken een commissie ingesteld om na te gaan hoe het functioneren van de bancaire sector kan worden verbeterd. Deze Commissie Maas komt in haar rapport Naar herstel van vertrouwen ${ }^{18}$ tot de conclusie dat het bestuur van een bank de belangen van spaarders, klanten, aandeelhouders, werknemers en de samenleving op een evenwichtige wijze moet afwegen, waarbij het primaat van die belangen bij de spaarders en klanten moet liggen. ${ }^{19} \mathrm{Zij}$ meent dat de afgelopen tien jaar de macht van de aandeelhouders in verhouding tot de andere stakeholders disproportioneel is toegenomen. Dit heeft geleid tot een te grote aandacht voor de winstontwikkeling op de korte termijn, en onvoldoende aandacht voor de andere bij de bank betrokken belangen. ${ }^{20}$

Het is veelzeggend dat deze stelling ook wordt betrokken door een door de sector zelf ingestelde commissie. Zij verbindt daaraan conclusies op het punt van variabele beloningen en van de aandeelhoudersstructuur. Zij geeft daarmee aan dat men er met goede bedoelingen alleen niet komt, maar dat het noodzakelijk is de governance van banken te wijzigen.

Wij menen inderdaad dat structurele wijzigingen in de manier waarop het beleid in financiële ondernemingen wordt bepaald, essentieel zijn om veranderingen te bewerkstelligen. Zolang de zeggenschapsstructuur niet aansluit bij de belangen die bij de onderneming zijn betrokken, valt niet te verwachten dat de disproportionele aandacht voor een van de belangen - het behalen van winst - verdwijnt. Dat verhindert het internaliseren van het publieke belang, en betekent daarmee dat een vorm van tweedelijns toezicht niet goed kan werken. Om in termen van het genoemde rapport over systeemtoezicht te spreken: de sterke oriëntatie op het behalen van winst verhindert dat de onderneming zich mede eigenaar voelt van het publieke belang. Wil men werkelijk tot verandering komen, dan moet ook de juridische structuur worden aangepast.

Daarvoor moet men in twee richtingen denken. In de eerste plaats zou de eenzijdige gerichtheid op winst op de korte termijn zodanig beperkt moeten worden, dat er ruimte ontstaat voor het nastreven van het publieke belang als doelstelling van de financiële onderneming zelf. In de tweede plaats zou, wanneer die ruimte is ontstaan, gezocht moeten worden naar een manier waarop die andere doelstelling - het behartigen van het publieke belang - een plaats kan krijgen in de structuur van de financiële onderneming.

Het begrip publiek belang wordt in dit verband gebruikt als een verzamelbegrip voor de belangen waarvoor de overheid een verantwoordelijkheid voelt, en die dus in regulering en toezicht worden nagestreefd. Daaronder vallen het algemene belang

I8. Commissie Maas, Naar hestel van vertrouwen, gepubliceerd op 7 april 2009. Te raadplegen op www.nvb.nl.

I9. Commissie Maas, Naar hestel van vertrouwen, p. I4 (aanbeveling I.II).

20. Commissie Maas, Naar hestel van vertrouwen, p. 2I. 
van een goed functionerende financiële sector, het belang van de bescherming van klanten en spaarders en het belang van transparante financiële markten.

\subsection{De positie van aandeelhouders}

Voor wat het eerste punt betreft kan het volgende worden gezegd. De verschaffers van risicodragend kapitaal in een vennootschap hebben doorgaans de positie van aandeelhouders. Er bestaan ook andere mogelijkheden - de risicodragende staatsdeelnemingen in banken laten dat zien - maar het aandeelhouderschap is de meest bekende vorm. Zoveel mogelijk uitgaande van de huidige regeling van de naamloze vennootschap betekent dit een vrij verhandelbaar aandeel in het eigendomsrecht en de winst van de financiële onderneming.

Dat levert op zichzelf geen strijd op met ruimte voor andere doelstellingen dan het behalen van winst. Die strijd kan wel bestaan wanneer de aandeelhouders tevens de dominante beleidsbepalers zijn. De strijd is het duidelijkst als aandeelhouders kunnen bereiken dat op korte termijn een hoge winst wordt gemaakt, terwijl de nadelen daarvan eerst op langere termijn spelen. Door tijdig de aandelen te verkopen, kunnen zij van het eerste profiteren en de nadelen van het laatste ontgaan. Hiermee kan aanzienlijke schade aan het publieke belang worden toegebracht omdat het beleid onvoldoende gericht is op winstgevendheid op de lange termijn en evenmin op de optimalisering van de publieke belangen op de korte en lange termijn.

Wil men dit voorkomen, dan zou de directe één op één relatie tussen aandeelhouderschap en bestuur moeten worden doorbroken. Het bestuur moet niet alleen de belangen van de aandeelhouders (op de korte termijn) behartigen en moet dus ook niet uitsluitend aan hen verantwoording verschuldigd zijn. Als de aansturing van de bestuurders en van het beleid in belangrijke mate in handen is van aandeelhouders, kan men niet verwachten dat andere belangen dan die van de aandeelhouders werkelijk een plaats zouden krijgen. Dat zou een altruïsme vergen dat men niet van aandeelhouders kan verwachten en dat in wezen ook niet functioneel is voor aandeelhouders. $^{2 \mathrm{I}}$

De ervaring leert dat het voor het aantrekken van risicodragend kapitaal niet nodig is de verschaffers ervan de positie van dominante beleidsbepalers te geven. De Rabobank doet het zonder aandeelhouders en sommige banken werkten of werken nog steeds met certificaten van aandelen, die geen zeggenschap in het beleid met zich meebrengen. Dat laatste heeft als bezwaar dat de bestuurders of commissarissen in feite nauwelijks aan een verantwoordingsplicht onderhevig zijn, hetgeen ook onwenselijk is. In onze benadering is een verantwoordingsplicht wel essenti-

2I. Hiermee is niet gezegd dat het publieke belang en het op winst gerichte belang van aandeelhouders steeds met elkaar in strijd zijn. De Commissie Burgmans constateert dat maatschappelijk verantwoord ondernemen ook vanuit commercieel gezichtspunt lonend kan zijn. Het moge zo zijn dat de commerciële invalshoek en die van de maatschappelijke of publieke belangen in elkaars verlengde kunnen liggen, dat is stellig niet steeds het geval. De huidige kredietcrisis laat dat duidelijk zien. 
eel, maar moet zij de vorm van een verantwoording voor alle betrokken belangen, inclusief de publieke belangen, krijgen.

Men zou zelfs kunnen aarzelen over de vraag of een beleidsbepalende invloed van de kapitaalverschaffers gewenst is. De noodzaak om hun belangen mede te dienen volgt direct uit de behoefte om risicodragend kapitaal aan te trekken. Daarmee wordt het voor de onderneming in ieder geval noodzakelijk om ook met hun belangen rekening te houden: de werking van de financiële markt is daarvoor voldoende. Zij behoeven voor dat doel echter geen directe zeggenschap in het beleid te verkrijgen. Zou men hen wel een zekere zeggenschap willen laten, dan zouden zij die in ieder geval moeten delen met de representanten van de andere belangen die bij de instelling betrokken zijn.

In het rapport van de Commissie Maas wordt met enige voorzichtigheid in deze richting gedacht. Certificering van aandelen wordt als mogelijkheid genoemd, en een langdurige relatie met aandeelhouders wordt aanbevolen, eventueel te ondersteunen met loyaliteitsdividend. ${ }^{22}$ Deze voorstellen zijn echter in die zin vrijblijvend, dat zij de vorm van aanbevelingen aan de banken hebben. Een verankering in wetgeving en toezicht wordt niet voorzien. Naar onze mening zou de kern van de zeggenschapstructuur in de wetgeving gelegd moeten worden, zodat ook de toezichthouder daarop kan toezien.

\subsection{Het internaliseren van publieke belangen}

Het tweede punt, het vormgeven van de eigen verantwoordelijkheid van de onderneming ten aanzien van het publieke belang, zou naar onze mening niet moeten gebeuren door de benoeming van een overheidsvertegenwoordiger met invloed op het beleid. Dat zou de overheidscommissaris van vroeger weer terugbrengen. Als men wenst dat financiële ondernemingen op de markt met elkaar concurreren, moeten zij niet alle vanuit dezelfde plaats - in de praktijk vanuit het ministerie van financiën - van opdrachten worden voorzien. Als deze vertegenwoordigers daadwerkelijk instructies van dat ministerie zouden krijgen, zou dat immers de mogelijkheden voor concurrentie verminderen: zij krijgen dan immers alle dezelfde instructies. Als geen instructies zouden worden meegegeven, zijn zij geen werkelijke vertegenwoordigers en moeten zij ook niet als zodanig worden beschouwd. Wij kunnen ons niet aan de indruk onttrekken dat de huidige staatsdeelnemingen de instellingen zelf, maar ook het publieke belang, niet of onvoldoende dienen.

Men moet juist naar wegen zoeken om het publieke belang zodanig in de instelling te verankeren, dat dit belang geïnternaliseerd wordt in de beleidsbepaling. Degenen die voor dit belang staan, moeten het beleid mede kunnen bepalen. Het gaat dus niet om een soort toezichthoudende rol, waarin wordt nagegaan of het beleid van de onderneming het publieke belang niet te sterk schaadt, maar om het bijdragen aan een zodanig beleid, dat het publieke belang zoveel mogelijk bevordert. Omdat de instelling met andere concurreert, moeten zij vanuit het belang waarvoor zij staat,

22. Commissie Maas, Naar herstel van vertrouwen, p. 25. 
bijdragen aan het ontwikkelen van producten die in vergelijking met die van concurrerende financiële ondernemingen superieur zijn. Superieur niet alleen vanuit het perspectief van winstgevendheid, maar ook gezien vanuit de publieke belangen. Ook het publieke belang kan sterk gebaat zijn met het inzetten van creativiteit op verschillende plaatsen om - ook in concurrentie met elkaar - de beste resultaten te bereiken.

Men zou dus binnen de instelling mensen moeten benoemen vanwege hun gerichtheid op de verschillende publieke belangen die aan de orde zijn. Voor zover het om publieke belangen gaat die de positie van bepaalde groepen betreft - het beschermen van cliënten of verzekerden, het garanderen dat voldoende krediet voor bedrijven en huishoudens beschikbaar komt - zou het moeten gaan om personen die daarop in het bijzonder zicht hebben. Om soortgelijke redenen als ten aanzien van de overheid is aangegeven, zouden zij niet als vertegenwoordigers van belangengroepen moeten optreden, maar onafhankelijk hun inbreng moeten leveren. Wel zou in hun benoemingsprocedure aandacht besteed kunnen worden aan de vraag of zij bij (organisaties van) betrokkenen voldoende vertrouwen bezitten. Voor de meer algemene aspecten van het publieke belang zouden onafhankelijke deskundigen kunnen optreden; vertrouwen bij de overheid of de toezichthouder zou op dezelfde wijze bij de benoeming een rol kunnen spelen.

Het is goed erop te wijzen dat wij niet aan een vormgeving denken die lijkt op de positie van de ondernemingsraad. Het gaat hier om personen in de raad aan wie het management verantwoording schuldig is, dus een raad die eerder te vergelijken is met een raad van commissarissen. Die raad zou een beleidsbepalende invloed moeten hebben en het management zou voor het gevoerde beleid aan de raad verantwoording moeten afleggen. De leden van de raad zouden op grond van hun deskundigheid benoemd moeten worden, waarbij naast deskundigheid op het terrein waarop de onderneming werkzaam is, ook inzicht in de diverse publieke belangen nodig is. Men zou eerder aan een constructie van een centrale bank moeten denken dan aan de nu gebruikelijke vennootschapstructuur, al zal de benoeming niet bij de overheid behoren te berusten.

Essentieel is bovendien dat de onderneming zich ook naar buiten verantwoordt voor de wijze waarop zij tewerk gaat. Voor wat de commerciële kant betreft bestaan die regels al. Voor de publieke belangen zouden vormen van verantwoording gevonden moeten worden die bij die belangen aansluiten. Wat dat betreft is te wijzen op de ontwikkelingen in publieke verantwoording die bij zelfstandige bestuursorganen vorm heeft gekregen. Instanties als de Sociale Verzekeringsbank leggen niet alleen verantwoording af over de wijze waarop zij de publieke belangen hebben gediend, maar worden daarop ook door onafhankelijke visitatie beoordeeld. ${ }^{23}$ De manier waarop door die organisaties wordt gewerkt aan de verbetering van de positie van de burger - goede toegankelijkheid, snelle klachtafhandeling ed. - zou inspiratie

23. Zie daarover het Handvest Publieke Verantwoording en de overige gegevens op www.publiekverantwoorden.nl. 
kunnen opleveren voor de wijze waarop het belang van de consument in de sfeer van een bank of een verzekeraar kan worden gediend.

Het gaat daar om publiekrechtelijke instellingen, zodat de structuur en wijze van verantwoording niet zonder meer voor privaatrechtelijke instellingen geschikt zijn. Maar de grote publieke belangen die bij banken en verzekeraars betrokken zijn dwingen tot het vinden van een vorm van publieke verantwoording voor de wijze waarop binnen die organisaties met de publieke belangen wordt omgegaan. Daarvoor kan wel degelijk geleerd worden van de nieuwe ontwikkelingen in het bestuursrecht.

Het is hier niet de plaats om de juridische structuur van de rechtspersoon verder uit te werken. Denkbaar is dat daarvoor een afzonderlijke vorm wordt ontwikkeld, denkbaar is ook dat men aansluit bij de huidige rechtspersoonsvormen. De rechtsvorm van de maatschappelijke onderneming, die volgens het regeerakkoord van het kabinet Balkenende IV zal worden ingevoerd, is waarschijnlijk geen goed aanknopingspunt, omdat zij vooral gericht is op instellingen in de semi-publieke sector (scholen, woningbouwcorporaties).

Uitgangspunt moet in ieder geval zijn dat de verantwoordelijkheid voor publieke belangen in de structuur tot uitdrukking wordt gebracht. Het bestuur moet verantwoording schuldig zijn aan een raad, waarin naast de commerciële invalshoek ook de publieke belangen verankerd zijn. Verantwoording en décharge van het bestuur vergt tevredenheid zowel bij degenen die voor het belang van aandeelhouders staan als van degenen die voor de publieke belangen staan. Beloningen die van prestaties afhangen moeten alleen worden toegekend wanneer die prestaties ook de publieke belangen betreffen. Het jaarverslag moet evenzeer de verrichtingen met betrekking tot de publieke belangen bespreken als de financiële resultaten.

Het beoordelen van financiële prestaties wordt doorgaans als eenvoudiger gezien dan dat van andere prestaties. In ieder geval is veel nauwkeuriger vastgelegd hoe de financiële uitkomsten beoordeeld moeten worden. De huidige crisis toont inmiddels aan dat de maatstaven daarvoor minder eenduidig zijn dan wel gedacht.

Voor het beoordelen van de kwaliteit van andere aspecten van het beleid worden wel steeds betere methoden ontwikkeld. Voor een aantal andere belangen, zoals de vraag of voldoende in het belang van de cliënt wordt gehandeld, is dat zeker goed mogelijk. Bedacht moet bijvoorbeeld worden dat het gebruik van best practices, benchmarking of andere kwalitatieve beoordelingsmogelijkheden gangbaar wordt. ${ }^{24}$ In het publiekrecht zijn met dergelijke verantwoordingsmethoden ook goede ervaringen opgedaan. Dat vergt overigens een voldoende mate van openbaarheid in verantwoording en verslaglegging. Bij sommige financiële ondernemingen, zoals pensioenfondsen, zijn vergelijkende beoordelingen en benchmarking inmiddels al gebruikelijk geworden.

24. De Commissie Burgmans wijst ook op het grote belang van best practices. Voor publiekrechtelijke instellingen zijn aanzienlijke vorderingen gemaakt met betrekking tot kwalitatieve beoordelingen. Men zie onder meer de resultaten van de Handvestgroep bij zelfstandige bestuursorganen. 
In de voorstellen van de Commissie Maas wordt ook aanbevolen dat andere belangen dan die van aandeelhouders bij de beleidsbepaling moeten worden betrokken, en zelfs dat het belang van de klant het zwaarste moet wegen. Maar hoe dat in de huidige structuur bereikt kan worden, wordt niet erg duidelijk. Het accent, ook bij het - met recht - stellen van de eis dat bestuurders en commissarissen voldoende deskundig moeten zijn, ligt op het terrein van bancair beleid en risico-management. Inzicht in de andere betrokken belangen lijkt niet verlangd te worden.

\subsection{Consequenties voor criteria voor beloningen}

Goede bedoelingen alleen zijn hierbij onvoldoende. Het publiekrecht leert ons dat daarop nimmer kan worden vertrouwd bij het vormgeven van een organisatie. Het op een of andere manier representeren van belangen die bij de besluitvorming een rol moeten spelen, het inbouwen van checks and balances en het zorgen voor goede verantwoordingsmechanismen en openbaarheid zijn essentieel om een organisatie goed te laten functioneren. De structuur en zeggenschap bij een organisatie zijn nu eenmaal bepalend voor de richting van het beleid en de inzet van prikkels om resultaten te behalen en moet dat in wezen ook zijn. Daarom moeten die zo zijn geregeld dat de belangen die bij de beleidsbepaling betrokken zouden moeten zijn, het beleid ook daadwerkelijk mede vorm geven.

In de huidige discussie spelen de beloningen van bankiers een grote rol. Die zouden de eenzijdige oriëntatie op korte termijn winst goeddeels veroorzaakt hebben. Naar onze overtuiging is er meer nodig dan het paal en perk stellen aan die beloningen. Het lijkt ons zelfs niet erg waarschijnlijk dat het beperken van die beloningen, bijvoorbeeld door die aan een maximum te binden, veel verschil zou maken. Het streven om de maximale bonus te behalen, ook al is die veel lager, blijft in een competitieve omgeving toch wel bestaan. ${ }^{25}$

Alleen indien de andere belangen in de structuur van zeggenschap en verantwoording een plaats hebben gekregen, zullen die ook meespelen in het beleid en de beloning. Zou men, zoals de Commissie Maas voorstelt, daadwerkelijk het belang van de klant centraal willen stellen, dan is het logisch gevolg van een dergelijke structuur dat de variabele beloning in de eerste plaats afhangt van de vraag of de bank tot de beste banken behoort op het punt van klanttevredenheid en zou de winstgevendheid een aanvullende, maar minder grote rol spelen. Gebeurt dat niet, dan is moeilijk vol te houden dat de klant centraal staat. ${ }^{26}$

Tegen deze achtergrond kunnen wij ons goed vinden in het commentaar van de AFM op het rapport van de Commissie Maas. ${ }^{27}$ De AFM onderschrijft de richting van denken van de commissie, maar meent ook dat dit niet alleen aan de zelfregulering

25. Zie de recente oratie van G.T.M.J. Raaijmakers, De financiële markt en het ondernemingsrecht, oratie Vrije Universiteit, Amsterdam, I6 juni 2009, paragraaf 4. Hij citeert op p. 39 Jeroen van de Veer, de oud-topman van Shell: 'If I had been paid 50 per cent more I would not have done it better. If I had been paid 50 per cent less, I would not have done it worse.'

26. In dezelfde richting gaat G.T.M.J Raaijmakers, De financiële markt en het ondernemingsrecht, oratie Vrije Universiteit, Amsterdam, r6 juni 2009, paragraaf 4, p. 39.

27. Bijlage bij Handelingen Tweede Kamer 2008-2009, 3I37I, no. 248. 
van de banken kan worden overgelaten. De Minister van Financiën heeft aangegeven nog terug te zullen komen op de vraag hoe het belang van de klant voldoende gewaarborgd kan worden. ${ }^{28}$

Naar onze mening geven deze beschouwingen zich nog onvoldoende rekenschap van de noodzaak de zeggenschapstructuur binnen de onderneming en de inrichting van het toezicht op elkaar af te stemmen. Indien men het belang van tweedelijnstoezicht of systeemtoezicht onderschrijft, is een noodzakelijke voorwaarde daarvoor dat binnen de onderneming een eigen verantwoordelijkheid wordt gevoeld voor het publieke belang. Dat vergt een internalisering van de relevante publieke belangen in de structuur van de onderneming. Daarover zwijgt de minister nog.

\section{Welke meer algemene conclusies kunnen uit het voorgaande over toezicht worden getrokken?}

\section{I Algemeen}

In hoeverre kunnen aan de voorgaande conclusies een meer algemeen karakter worden toegekend?

Aan de ene kant is duidelijk dat de financiële sector een specifieke sector is. De strategische positie van financiële instellingen in de economie brengt met zich mee dat het publieke belang zeer sterk betrokken is bij het goed functioneren van die sector. Bovendien brengt de aard van veel financiële producten met zich mee dat zij risico's insluiten die een goede marktwerking en een goede beoordeling van de solvabiliteit bemoeilijken. Consumenten kunnen door asymmetrie in professionaliteit zelfs levenslang de nadelen ondervinden van de aanschaf van producten met een te groot risico. Daarom is het niet mogelijk om de voorgaande beschouwingen over financieel toezicht zonder meer toe te passen op toezicht bij andere sectoren van het economisch leven.

Aan de andere kant zijn er ook overeenkomsten tussen de vraagstukken omtrent regulering en toezicht die in de financiële sector spelen en in het toezicht in andere sectoren. Wij zullen daarover enkele opmerkingen maken, die een verkennend karakter hebben. Dat hangt samen met het feit dat wij geen studie hebben gemaakt van andere sectoren, zodat het mogelijk is dat wij specifieke omstandigheden over het hoofd zien die tot andere conclusies moeten leiden. Hieronder zal de energiesector in het bijzonder ter sprake komen, omdat onze Belgische collega's daarover schrijven. Vervolgens zullen nog enkele opmerkingen worden gemaakt over het huidige streven om privaatrechtelijke organisaties een zekere verantwoordelijkheid

28. Brief van 24 augustus 2009, Handelingen Tweede Kamer 2008-2009, 31371, no. 248. Zie ook W.J. Oostwouder Naar herstel van vertrouwen?, Onderneming en Financiering 2009 (17) 2, p.I4, p.27, die kritiek uit op het centraal stellen van de klant vanuit een vennootschapsrechtelijk oogpunt. Wel lijkt hij genegen te zijn het maatschappelijke belang te verankeren. Naar onze mening zou, wellicht anders dan Oostwouder meent, het vennootschappelijke belang tevens het maatschappelijk belang moeten meenemen. 
voor publieke belangen toe te delen. Maatschappelijk verantwoord ondernemen is daarvoor de vaak gebruikte aanduiding.

\subsection{Andere sectoren, met name de energiesector}

Het betoog over regulering en toezicht in de financiële sector is gebaseerd op de gedachte dat mededinging op de markt van groot maatschappelijk belang is, ook omdat daardoor vooruitgang en innovatie bevorderd worden. Toezicht en regulering zijn nodig omdat het publieke belang zeer sterk betrokken is bij het goed functioneren van de sector. Omdat kennis en professionaliteit een grote rol spelen, dient die regulering daarbij aan te sluiten door met voldoende open normen te werken die ondernemingen de ruimte laten om te zoeken naar de beste manier om het publieke belang te dienen. Het toezicht dient dan het karakter van tweedelijns toezicht (systeemtoezicht) te hebben. Voorwaarde voor de goede werking van een dergelijke benadering is dat de financiële instellingen zodanig zijn gestructureerd dat het publieke belang daarbinnen een plaats heeft gekregen. Dat houdt in dat andere belangen dan die van aandeelhouders in de zeggenschapsstructuur aanwezig moeten zijn.

Deze gedachtegang zou in andere sectoren bruikbaar zijn indien marktwerking gewenst is om vernieuwing en vooruitgang te stimuleren, terwijl het publieke belang dat niet via de markt wordt behartigd specifieke regulering en toezicht vereisen. ${ }^{29}$ Het moet dan gaan om sectoren waarin professionaliteit een belangrijke rol speelt, omdat de argumenten ten gunste van open normstelling en tweedelijns toezicht daarop berusten.

Op het eerste gezicht lijkt de energiesector aan deze kenmerken te voldoen. In het verleden waren de energiebedrijven in Nederland in handen van - meestal - decentrale overheden, hetgeen het grote publieke belang van deze sector illustreert. Marktwerking is inmiddels tot stand gebracht doordat afnemers vrij zijn in het kiezen van een leverancier. Bovendien zijn of worden de energiebedrijven geprivatiseerd, zodat de aandelen niet meer in handen van de overheid zijn. Door overnames en fusies hebben buitenlandse bedrijven inmiddels een grote invloed gekregen op de Nederlandse energiemarkt.

Het publieke belang kan daardoor niet langer worden gediend langs de weg van het aandeelhouderschap. Daarvoor wordt nu gewaakt door speciale wetgeving in de Elektriciteitswet 1998 en de Gaswet. Het toezicht wordt uitgeoefend door de Nma (Nederlandse mededingsautoriteit), en ligt in feite in handen van de Energiekamer van de Nma. Voor elektriciteit wordt het transportnet onder een afzonderlijke beheerder gebracht, dat los moet staan van de producenten. Hiervoor gelden nog weer speciale regels; het onderstaande heeft daarom uitsluitend betrekking op de producenten en leveranciers van stroom.

29. Het generieke markttoezicht via het mededingingsrecht blijft hier buiten beschouwing. 
De publieke belangen die hier in het spel zijn, bestaan voor een deel uit het beschermen van de positie van de individuele gebruiker - met onder meer de gedachte dat afsluiting van energievoorziening van burgers zoveel mogelijk moet worden voorkomen, in ieder geval in de winter - en voor een deel uit meer algemene belangen, waaronder stroomzekerheid en duurzaamheid.

De vraag hoe deze publieke belangen het beste bevorderd kunnen worden, is voor een aanzienlijk deel een kwestie van professionaliteit. De opwekking van (duurzame) energie, het realiseren van besparingen in het energiegebruik en het verzekeren van stroomzekerheid vergen creativiteit en innovatie. Leveranciers en producenten zijn doorgaans grote professionele instellingen. $\mathrm{Zij}$ moeten dus uitgedaagd worden om hun professionaliteit mede voor die doelstellingen in te zetten.

De verhouding tussen leverancier en afnemer is duidelijk verschillend van die tussen een financiële instelling en een klant. Het gaat om geheel andere producten en ook de problematiek van de risico's speelt aanzienlijk minder. Het lijkt voor een goed deel mogelijk om door algemene regels veel aspecten van die verhouding goed te regelen. Toch is de afhankelijkheid van leverancier groot en wordt de leverancier daarom door de wetgever opgedragen zich het belang van de wederpartij aan te trekken. Een heel concreet voorbeeld daarvan is al genoemd: afsluiting van een particulier in de winter moet voorkomen worden. Kenmerkend voor de asymmetrie die de wetgever ziet tussen leverancier en afnemer is dat de afnemers óók als zij bedrijven zijn, zich op de regels over consumentenbescherming uit het Burgerlijk Wetboek mogen beroepen, terwijl die regels juist niet zijn geschreven zijn voor bedrijven.

Tegen deze achtergrond zou veel van hetgeen hierboven voor de financiële sector is gezegd, ook van toepassing zijn op de energiesector. Regulering met behulp van open normen is gewenst om creativiteit en innovatie te bevorderen. Ver doorgevoerde, strakke regulering zal de voordelen van de marktwerking teniet kunnen doen en moet daarom worden vermeden. Een stelsel van tweedelijns toezicht sluit hierbij het beste aan. Het gaat ervan uit dat de private onderneming of instelling in eerste instantie een eigen professionele verantwoordelijkheid heeft; het toezicht moet er op gericht zijn na te gaan of die verantwoordelijkheid voldoende wordt genomen

In de wetgeving is die benadering op een aantal plaatsen ook terug te vinden. In de Elektriciteitswet is op het punt van duurzaamheid de eigen verantwoordelijkheid van de onderneming voorop gesteld. Die moet een plan maken om duurzaamheid te bevorderen, onder meer door te stimuleren tot het voorkomen van nodeloos energiegebruik. Op de genoegzaamheid van het aldus ingezette ondernemingsbeleid wordt dan toezicht uitgeoefend.

Voor ondernemingen die in deze positie verkeren, gaat ook op hetgeen voor banken en verzekeraars is gesteld omtrent hun interne structuur. Indien het privaatrecht de zeggenschapsverhoudingen binnen de onderneming zodanig vorm geeft, dat de daarvan uitgaande prikkels haaks staan op het publieke belang, dan is het haast onmogelijk om daartegen door regulering en toezicht een voldoende tegenwicht te bieden. Evenals in de financiële sector doet zich dat gevaar in de energiesector 
ook voor. Publieke belangen die hier spelen, zoals het bevorderen van besparing op energie, het duurzamer maken van de stroomopwekking, het garanderen van de stroomzekerheid en het zoveel mogelijk voorkomen dat afnemers afgesloten worden, zijn doelstellingen die in strijd kunnen komen met het behalen van winst.

Deze problematiek speelde veel minder zolang overheden de aandeelhouders waren van de ondernemingen op de energiemarkt. Van deze aandeelhouders valt immers te verwachten dat zij het publieke belang mede in de beschouwing betrekken en het behalen van winst op korte termijn niet als enige belang beschouwen. Maar wanneer deze aandeelhouders vervangen worden door private partijen, die dit belang als aandeelhouder wel vooropstellen, ontstaat een andere situatie. Dan geldt hetzelfde als voor ondernemingen in de bancaire sector moet gelden: in de zeggenschapstructuur van de onderneming moet een plaats worden ingeruimd voor de publieke belangen die bij de onderneming betrokken zijn. Alleen dan zal de onderneming zich mede 'eigenaar' voelen van die belangen en de professionele inventiviteit ook aanwenden om die doelen te bereiken. Tweedelijns toezicht kan daarop aansluiten. Zonder internalisering van de publieke belangen bestaat steeds het gevaar dat de creativiteit van de onderneming eenzijdig gericht zal zijn op het behalen van winst, met inbegrip van het zo goed mogelijk omzeilen van het toezicht voor zover dat hiermee in strijd zou zijn. De indruk bestaat dat bijvoorbeeld de beloningsstructuur bij geprivatiseerde energiebedrijven inderdaad uitsluitend op dat doel is gericht.

\subsection{Enkele meer algemene observaties}

Financiële sector en energiesector niet representatief

De financiële sector en de energiesector zijn sectoren die niet representatief zijn voor de economie als geheel. Bij beide is het publieke belang zeer nauw betrokken, en is de noodzaak voor toezicht en regulering ook groot. Voor andere sectoren zal een dergelijk intensief toezicht niet nodig zijn. Dat betekent ook dat voorzieningen in de privaatrechtelijke structuur van ondernemingen die voor de beide hier besproken sectoren aan de orde zijn, daar veel minder voor de hand liggen. In onze benadering zou dus een meer gedifferentieerd privaatrechtelijk organisatierecht of vennootschapsrecht nodig zijn. Die differentiatie zou dan afhangen van de mate waarin publieke belangen een plaats in de privaatrechtelijke structuur van de onderneming moeten krijgen.

Een belangrijk aandachtspunt is daarbij in hoeverre er een tegenstelling bestaat tussen het publieke belang waarvoor een eventuele toezichthouder staat en de prikkels die uit de private structuur voortvloeien. Indien juist is wat uit het aangehaalde rapport van de WRR en het studie van het WODC voortvloeit, namelijk dat tweedelijnstoezicht of systeemtoezicht in de huidige kennisintensieve samenleving van steeds groter belang wordt, dan groeit het belang van aandacht voor die tegenstelling.

Niet in iedere sector is die tegenstelling even groot. Zo wordt in de studie van het WODC het geval van het toezicht op de veiligheid van vliegtuigen behandeld. De belangen van luchtvaartonderneming en toezichthouder lopen hier veel meer 
parallel, omdat een luchtvaartmaatschappij het belang van de veiligheid niet kan negeren: een neerstortend vliegtuig is in alle opzichten een ramp, ook voor de onderneming. De onderneming zou dan ook zonder enig toezicht een eigen veiligheidssysteem opzetten en het toezicht kan daar op aansluiten. Om die reden bestaat er al een lange ervaring met systeemtoezicht in die sector.

Naarmate het tweedelijns toezicht van groter belang wordt, zal de noodzaak toenemen om daarvoor een inbedding te vinden waarin de onder toezicht gestelde zich mede verantwoordelijk voelt voor het publieke belang en daarvan - in de termen van de studie over systeemtoezicht - mede als eigenaar daarvan gaat optreden. Dat moet consequenties hebben voor de privaatrechtelijke structuur van de onderneming.

Tegelijkertijd zijn er in het vennootschapsrecht ontwikkelingen te signaleren, die voor deze problematiek relevant zijn.

Beperking van gerichtheid op aandeelhoudersbelang in het algemeen

Als gevolg van de beperkte controle op het bestuur van (beursgenoteerde) ondernemingen, was er in Nederland eind vorige eeuw en begin van deze eeuw een tendens om de aandeelhouders meer invloed te geven in deze ondernemingen. ${ }^{30}$ De gerichtheid op aandeelhouderswaarde heeft in Nederland geresulteerd in één van de meest open stelsels en is ten koste gegaan van het Stakeholdersmodel. ${ }^{\mathrm{I}}$

Mede als gevolg van de crisis lijkt de eenzijdige nadruk op (korte termijn) aandeelhouderswaarde in Nederland veel terrein te verliezen. Van verschillende kanten wordt betoogd dat de structuur van ondernemingen niet (enkel) gericht moet zijn op korte termijnbelangen van aandeelhouders. Daarbij zijn twee benaderingen zichtbaar. Soms wordt ervoor gepleit dat ondernemingen met name gericht moeten zijn op aandeelhoudersbelangen op lange termijn. Ook wordt er voor gepleit om de belangen van andere betrokken beter vorm te geven in het Stakeholdersmodel (of het Rijnlandse model in tegenstelling tot het Angelsaksische model). In deze gedachte zijn aandeelhouders één van de belanghebbenden, maar niet noodzakelijkerwijs de dominante belanghebbende. Deze laatste benadering is in Nederland goed zichtbaar. Raaijmakers heeft in zijn oratie helder weergegeven dat een enkele nadruk op aandeelhoudersbelangen, ook die op lange termijn, vaak onvoldoende effectief zal zijn om het maatschappelijk wenselijke resultaat te bereiken. De disciplinerende werking van de financiële markt is vaak onvoldoende en de belangen van de financiële markt lopen niet steeds parallel met het door maatschappij gewenste resultaat. ${ }^{32}$

Deze ontwikkeling om ondernemingen meer op lange termijn gericht te laten zijn en meer gericht te laten zijn op de maatschappelijke belangen, sluit goed aan bij ons betoog voor de financiële sector en energiesector. De achterliggende gedachte is dat de interne organisatie en de verantwoording van een onderneming in zekere

30. G.T.M.J Raaijmakers, De financiële markt en het ondernemingsrecht, oratie Vrije Universiteit, Amsterdam, I6 juni 2009, paragraaf 2, i.h.b. p. 9.

3I. G.T.M.J Raaijmakers, De financiële markt en het ondernemingsrecht, oratie Vrije Universiteit, Amsterdam, I6 juni 2009, paragraaf 4, i.h.b. p. 4I.

32. G.T.M.J Raaijmakers, De financiële markt en het ondernemingsrecht, oratie Vrije Universiteit, Amsterdam, I6 juni 2009, paragraaf 4, i.h.b. p. 34 . 
mate in lijn moet liggen met de maatschappelijke belangen. De enkele gerichtheid op (korte termijn) financiële belangen zal in bepaalde gevallen immers haaks staan op het maatschappelijk wenselijke gedrag. Het ligt naar onze mening dan ook voor de hand dat met het oog hierop de structuur en verantwoording van (beursgenoteerde) ondernemingen, in het algemeen wordt aangepast om meer ruimte te geven voor andere belangen dan enkel het (korte termijn) aandeelhoudersbelang. Vervolgens kan in de privaatrechtelijke structuur van de onderneming de bovengenoemde differentiatie worden aangebracht naar de mate waarin publieke belangen een rol spelen.

\section{Maatschappelijk verantwoord ondernemen}

De toenemende belangstelling voor maatschappelijk verantwoord ondernemen is in dit verband interessant. Veel bedrijven laten weten dat zij dit belangrijk vinden, en ook de regering heeft zich daarbij aangesloten.

Kern is dat private bedrijven zich niet alleen moeten richten op het maken van winst, maar ook een bijdrage moeten leveren aan maatschappelijke belangen. Duurzaamheid, het voorkomen van kinderarbeid en een goed personeelsbeleid worden tot die belangen gerekend. Tot nu toe heeft dit wel geleid tot een grotere bewustwording van de problematiek en tot het afleggen van verantwoording over aspecten ervan door een aantal ondernemingen, maar niet tot de gedachte dat deze belangen in het privaatrechtelijk ondernemingsrecht een plaats krijgen toebedeeld.

Toch zou men - in het verlengde van dit preadvies - kunnen betogen dat deze benadering niet tot wasdom kan komen zolang zij niet een zekere weerspiegeling vindt in de structuur van de privaatrechtelijke organisatie. Zoals gezegd heeft de Commissie Burgmans bepleit dat iedere onderneming een beleid voert, gericht op haar maatschappelijke verantwoordelijkheid. In aansluiting daarop stelt de Commissie Frijns in haar recente rapport over beloningen van bestuurders voor dat beloningen mede moeten worden afgestemd op de mate waarin de onderneming bepaalde publieke belangen heeft gediend. Maar zij stelt geen enkele structurele maatregel voor om dit te bereiken. Het lijkt ons onrealistisch dat een dergelijk doel bereikt kan worden zolang de zeggenschap van de kapitaalverschaffers in de onderneming zo dominant is.

\subsection{Internationale aspecten}

$\mathrm{Nu}$ het hier gaat om een preadvies voor een internationale vereniging, is enige aandachtvoor de internationale aspecten op zijn plaats. Financiële markten zijn in sterke mate geïnternationaliseerd en dat geldt ook steeds meer voor de energiemarkt. Dit betekent dat een nationaal georganiseerd stelsel van regulering en toezicht steeds minder effectief is. Internationale samenwerking is dan ook essentieel.

Binnen Europa wordt op het punt van regulering een zekere voortgang geboekt, maar de inrichting van het toezicht blijft nog sterk nationaal georganiseerd. Dat geldt nog sterker indien men de rest van de wereld in de beschouwingen betrekt. Zeker voor de financiële sector is dat noodzakelijk. 
Het leidt geen twijfel dat het toezicht op een grensoverschrijdende markt daardoor minder effectief zal zijn dan het toezicht op een nationale markt kan zijn. Zelfs indien men regelgeving en beleid op elkaar kan afstemmen, zijn de problemen op het punt van afstemming en samenwerking over de grenzen heen zo ingewikkeld, dat de slagvaardigheid daar onvermijdelijk onder leidt. Zo vallen er gemakkelijk 'gaten' in het toezicht. Dat is het geval geweest bij het toezicht op banken die in een bepaald land hun hoofdkantoor hebben, en daarnaast kantoren in andere landen openden. Noch de toezichthouder van het land waar het hoofdkantoor was gevestigd, noch dat waar andere kantoren waren geopend, bleek effectief toezicht uit te oefenen op hetgeen er buiten het land van het hoofdkantoor gebeurde. 33

In de praktijk is overeenstemming over de inrichting van de regulering en het toezicht maar zeer beperkt aanwezig. Dat bemoeilijkt een effectief toezicht op grensoverschrijdende markten uiteraard sterk.

Dit betekent dat de noodzaak om de publieke belangen een plaats te geven in ondernemingen die grensoverschrijdend werken, sterk toeneemt. Indien men binnen een nationaal kader al tot de conclusie komt dat de overheid alleen niet in staat is met regulering en toezicht de publieke belangen te beschermen, maar daarvoor tevens een eigen verantwoordelijkheid daarvoor bij private ondernemingen nodig is, dan geldt dat nog veel sterker in een transnationale omgeving. Daar is het toezicht inherent minder effectief dan binnen een staat. Er bestaat dus een nog grotere noodzaak om de publieke belangen binnen de instellingen te internaliseren, en de structuur daarbij ook aan te passen.

Naar onze mening is dit een sterk ondersteund argument voor onze stelling dat financiële instelling een zeggenschapsstructuur moeten hebben waarin ook andere belangen dan die van de aandeelhouders een plaats krijgen. Het zou kunnen zijn dat bij grensoverschrijdende markten langs die weg tenminste even effectief tewerk kan worden gegaan als langs de lijn van het versterken van het toezicht.

Daarbij past uiteraard wel de aantekening dat ook hier internationale afstemming over de hoofdlijnen noodzakelijk is. De eisen die verschillende landen aan financiële instellingen stellen moeten niet met elkaar in strijd zijn. Bovendien zal men moeten nagaan in hoeverre de internationale concurrentiepositie van banken en andere ondernemingen hierdoor wordt verzwakt.

\section{$7 \quad$ Aansprakelijkheid van toezichthouders}

De aansprakelijkheid van toezichthouders heeft zich ontwikkeld tegen de achtergrond van de aansprakelijkheid van de overheid in het algemeen. Die aansprakelijkheid is in de afgelopen kwart eeuw groter geworden. Met name de gedachte dat na een onrechtmatig handelen van de overheid het de voorkeur verdient de nadelige gevolgen daarvan voor rekening van de gemeenschap te brengen en niet ten laste te

33. Zie bijvoorbeeld het rapport van Lord Turner, voorzitter van de Engelse toezichthouder, de FSA: Turner Review, te raadplegen op www.fsa.gov.uk/pages/Library/Corporate/turner/index.shtml. 
laten komen van degene die door de fout is benadeeld, heeft wortel geschoten. Het beginsel van de gelijkheid voor de publieke lasten klinkt daarin door. Het gevolg hiervan is dat het vraagstuk van de toerekening of schuld geen rol meer speelt bij overheidsaansprakelijkheid.

Bij de aansprakelijkheid van toezichthouders kan men aan twee vormen denken. In de eerste plaats gaat het om de aansprakelijkheid van de toezichthouder jegens de onder toezicht gestelde instelling. Als een vergunning wordt geweigerd of ingetrokken, of een andere handeling in het kader van het toezicht wordt verricht, en deze blijkt onrechtmatig te zijn - bijvoorbeeld doordat het besluit tot weigering of intrekking wordt vernietigd - dan is de toezichthouder aansprakelijk voor de daardoor veroorzaakte schade. De huidige stand van het recht is op dit punt in beginsel duidelijk, en daarover is ook weinig discussie. Het gaat hier om de toepassing van de algemene regels over overheidsaansprakelijkheid. In de praktijk ontstaan vooral problemen doordat zowel de gewone rechter als de bestuursrecht zich met deze problematiek bezig (moeten) houden.

Veel lastiger is het vraagstuk van de aansprakelijkheid van de toezichthouder wanneer het toezicht faalt en er door een onder toezicht staande instelling wordt gehandeld op een manier die het toezicht juist had moeten voorkomen. Een financiële instelling gaat bijvoorbeeld failliet omdat zij te veel risico heeft genomen, hetgeen de toezichthouder niet heeft verhinderd. Kunnen derden - zoals crediteuren (spaarders) of aandeelhouders - hun schade dan vergoed krijgen? De discussie daarover is van recenter datum, en heeft in onze beide landen voorlopig ook tot een verschillend resultaat geleid.

\section{I Aansprakelijkheid voor falend toezicht naar huidig recht}

In het algemeen zal bij het falen van toezicht gelden dat in eerste instantie degene op wie het toezicht wordt uitgeoefend, aansprakelijk is. Is er met een onveilige boot gevaren en ontstaat daardoor schade, dan zal de eigenaar of de reder van de boot aansprakelijk zijn. De aansprakelijkheid van de toezichthouder komt aan de orde omdat verhaal op de onder toezicht gestelde vaak moeilijker of geheel onmogelijk is, terwijl de toezichthouder veel meer kans op verhaal biedt. Dat laatste is zeker het geval indien falen van het financiële toezicht leidt tot het omvallen van een financiele instelling. Bij de teloorgang van de verzekeraar Vie d'Or was dit de inzet van de procedure door gedupeerde verzekerden.

In Nederland is veel aandacht aan deze aansprakelijkheid besteed. Een van de preadviezen voor de NJV in $2005^{34}$ was aan het onderwerp gewijd. Daarna is in opdracht van het WODC een rapport over dit onderwerp geschreven door Van Dam.35 Specifiek voor het toezicht in de financiële sector is in opdracht van het Ministerie van

34. A.A. van Rossum, Civielrechtelijke aansprakelijkheid voor overheidstoezicht, samen met L.F.M.Verheij en N. Verheij, De macht van marktmeesters, Martktoezicht in constitutioneel perspectief, de preadviezen NJV over Toezicht, Deventer 2005.

35. Cees C. van Dam, Aanprakelijkheid van Toezichthouders, Britisch Institute of International and Comparative Law, 2006. 
Financiën nog een aanvullende studie gedaan; in deze studie ging het vooral om de vraag of verschillen in nationale aansprakelijkheidsregimes tot extra risico's voor aansprakelijkheid van de Nederlandse toezichthouders kan leiden. ${ }^{6}$

Op basis van deze verschillende studies kan gezegd worden dat de rechter als maatstaf voor aansprakelijkheid hanteert of het toezicht voldoet aan de eisen van een behoorlijk en zorgvuldig toezicht. De Hoge Raad noemt in het Vie d'Or arrest een groot aantal gezichtspunten die relevant zijn voor het invullen van deze algemene norm. Aan de toezichthouder wordt daarbij een aanzienlijke beleids- en beoordelingsvrijheid gegund, maar het gebruik daarvan wordt wel duidelijk getoetst. ${ }^{37}$ Een eerder arrest van de Hoge Raad (duwbak Linda) ${ }^{38}$ had de indruk gewekt dat de relativiteitseis nog een belangrijke hinderpaal op weg naar aansprakelijkheid zou zijn, maar uit het Vie d'Or arrest blijkt dat dit niet in algemene zin gesteld kan worden. Het hangt af van de beweegredenen bij het instellen van het toezicht.

\subsection{Uitsluiting van aansprakelijkheid?}

Het Bazel comité, waarin centrale banken samenwerken, heeft zich uitgesproken ten gunste van vergaande uitsluiting van aansprakelijkheid van financiële toezichthouders omdat hun werk anders belemmerd zou kunnen worden door de vrees voor claims. ${ }^{39}$ Daarom is aan de nationale overheden aanbevolen financiële toezichthouders immuniteit te verlenen ten opzicht van claims wegens onjuist toezicht.

De Nederlandse wetgever heeft daartoe niet besloten, maar de Belgische heeft dit advies wel opgevolgd, zo blijkt uit het rechtsvergelijkende deel van de studie van Giessen c.s. In die studie wordt ook niet aanbevolen om de aanbeveling voor Nederland te volgen. De onderzoekers vinden de risico's van aansprakelijkheid beperkt 'want de geruststellende conclusies op basis van het rapport Van Dam blijven recht overeind. Naar Nederlands recht wordt aansprakelijkheid van een toezichthouder niet snel aangenomen'. ${ }^{\circ}$

Hoewel wij de conclusie delen dat aansprakelijkheid van een toezichthouder niet snel zal worden aangenomen zolang hij zijn werk zorgvuldig verricht en er ook geen feitelijke onderbouwing bestaat voor de stelling dat de aansprakelijkheid de toezichthouder zou kunnen belemmeren, kijken wij toch anders aan tegen het risico. Zolang het niet gaat om risico's die onbeheersbaar worden, bestaat er inderdaad geen goed argument voor een specifieke regeling van immuniteit voor financiële toezichthouders. Waarom zou dezelfde redenering dan niet moeten gelden voor andere toezichthouders? Voor Belgie zou de vraag interessant kunnen zijn of ook de toezichthouders in de energiesector op dezelfde manier behandeld moeten worden als de financiële toezichthouder.

36. Ivo Giesen, Evelien de Kezel, Cees van Dam en Edgar du Perron, Aansprakelijkheid in international verband, Ministerie van Financiën 2009.

37. Zie HR I3 oktober 2006, NJ 2008, 527 m.nt. C.C. van Dam en het rapport, genoemd in de vorige noot, p. 43-45.

38. HR 7 mei 2004,

39. Zie daarover Giessen c.s., Aansprakelijkheid in internationaal verband, p. 47.

40. Giessen c.s., Aansprakelijkheid in international verband, p. I4. 


\subsection{Geen uitsluiting, maar wel maximering aansprakelijkheid financiële toezichthouder}

De ervaring heeft echter geleerd dat de risico's in de financiële sector - indien zij optreden en tot aansprakelijkheid leiden - wel degelijk onbeheersbaar kunnen worden. Indien een toezichthouder een fout maakt die het omvallen van een majeure financiële instelling ten gevolge heeft, kan de schade zeer groot zijn en de draagkracht van de Nederlandse staat zwaar belasten of zelfs overstijgen. Nu is juist dat de aansprakelijkheid niet snel wordt aangenomen indien er geen grote fouten worden gemaakt. Maar die laatste zijn niet geheel uit te sluiten. In iedere grotere organisatie gaat er wel eens iets grondig mis, vaak als gevolg van een ongelukkige samenloop van omstandigheden. Men denke aan een combinatie van ziekte, computerstoring of een ernstige miscommunicatie binnen de toezichthouder. Het lijkt erop alsof de financiële toezichthouder in Italië (corruptie president Centrale Bank) als IJsland (Icesave affaire) hebben gehandeld op een wijze die hen naar de nu geldende normen van Nederlands recht aansprakelijk hadden gemaakt. Men kan veronderstellen dat een dergelijke situatie zich in Nederland nooit zal voordoen. De valkuil van toekomstonderzoek is echter dat men geen rekening houdt met gebeurtenissen of combinaties van omstandigheden die ieder op zichzelf heel onwaarschijnlijk zijn, terwijl in de praktijk blijkt dat een geheel onverwachte gebeurtenis zich toch met enige regelmaat voordoet.

Gezien het feit dat in de financiële sector het risico van aansprakelijkheid van de toezichthouder tot een onbeheersbaar niveau kan stijgen, zouden wij aanbevelen uitsluitend voor dat geval een wettelijke voorziening te treffen. Die zou niet moeten bestaan uit het in het algemeen anders regelen van de aansprakelijkheid van de financiële toezichthouder - in beginsel moeten alle vormen van toezicht op dezelfde wijze behandeld worden - maar in het stellen van een maximum aan de aansprakelijkheid. Dat zou heel hoog kunnen zijn, bijvoorbeeld een miljard euro, maar zou moeten voorkomen dat de Nederlandse staat tegen onbeheersbare risico's wordt beschermd. 